\title{
Spatial and temporal variation in benthic macrofauna and relationships with environmental variables in an estuarine, intertidal soft-sediment environment
}

\author{
Tom Ysebaert*, Peter M. J. Herman
}

Netherlands Institute of Ecology, Centre for Estuarine and Marine Ecology, PO Box 140, 4400 AC Yerseke, The Netherlands

\begin{abstract}
We quantified the distribution, abundance, biomass and assemblage structure of benthic macrofauna at different spatio-temporal scales in a temperate estuarine, intertidal soft-sediment environment in the Schelde estuary, The Netherlands. Hierarchically scaled surveys were conducted yearly between 1994 and 2000, covering 4 spatial scales: region $\left(10^{4} \mathrm{~m}\right)$, transect $\left(10^{3} \mathrm{~m}\right)$, station $\left(10^{2} \mathrm{~m}\right)$, and replicate samples $\left(10^{-1} \mathrm{~m}\right)$. Our approach provided a powerful framework for quantifying the proportion of the variation among samples that was attributable to each spatial or temporal scale, and we explicitly aimed at identifying the role of environmental variables in explaining the observed variability. Variance components calculated for 11 dominant macrobenthic species revealed that variations at the scale of stations and year $\times$ station interactions were the most important components of variability. Regional and transect differences were only apparent for a few species, although multivariate analysis revealed clear inter-regional differences for the macrobenthic assemblage structure. Only a few species displayed significant variability associated with the factor year solely. Both spatial and temporal components explained $>70 \%$ of the total variance. A substantial part of the total variation in abundance of individual species was explained by the observed environmental variables (27 to $56 \%$ ). Multiple regression with subdivision of the environmental variables into a long-term average and a temporal component showed that the long-term averages were much more important than the short-term deviations from this average, with local environmental variables (mud content, chlorophyll $a$, bed level height) explaining the largest part of the observed variation. For a few species and total biomass, salinity also explained a large part of the observed variation. Canonical correspondence analysis (CCA) with forward selection revealed that salinity and mud content, and to a lesser extent chlorophyll $a$ and bed-level height, accounted for most of the variance in the macrobenthic species data. Partial CCA indicated that of the variation in the species data a large part was spatially structured $(56.7 \%)$, with about half of this variation being explained by the environmental variables used. Only $4.1 \%$ of the species variation was temporally structured. Our results have important consequences for both the interpretation of monitoring programmes and the enhancement of sampling designs.
\end{abstract}

KEY WORDS: Spatial and temporal scale $\cdot$ Hierarchical ANOVA · Variance components $\cdot$ Multivariate analysis $\cdot$ Variation partitioning $\cdot$ Intertidal soft-sediment communities $\cdot$ Schelde estuary

\section{INTRODUCTION}

Ecological communities vary across different spatial and temporal scales (Andrew \& Mapstone 1987, Wiens 1989, Barry \& Dayton 1991, Schneider 1994, Horne \&

*Email: t.ysebaert@nioo.knaw.nl
Schneider 1995). Identification of the relevant scales of variability in space and time is a prerequisite to understanding factors and processes generating patterns in biotic and abiotic components of ecosystems (Levin 1992). Quantitative description and observation of patterns at several spatial and/or temporal scales is a fundamental step in the scientific process from which 
questions and hypotheses arise and from which appropriate predictive models can be proposed (Levin 1992, Constable 1999, Thrush et al. 1999, Underwood et al. 2000). Especially in estuaries, characterised by a high degree of spatial and temporal variability, this is a prerequisite for a sound implementation of integrated management, as it will allow better predictions about future environmental changes due to human impacts (Thrush et al. 1999).

In the estuarine ecosystem, macrobenthos is one of the structuring elements of the food web, and it plays an important role in the system dynamics (Herman et al. 1999). Macrobenthos is a key element of many marine and estuarine monitoring programmes, but usually these programmes do not (or cannot) explicitly take into account distribution patterns at different spatio-temporal scales. We have recently shown that predictive statistical models based on such an amalgamated approach may be highly successful in hindcasting presences and absences of species as a function of abiotic variables (Ysebaert et al. 2002). However, the forecasting predictive power of such models under (anthropogenically) changed forcing remains to be validated, because a change in forcing may decouple correlations between large- and small-scale variation in abiotic or biotic conditions. To overcome this problem, recent studies in the marine environment in general and in soft sediments in particular have increasingly employed hierarchical sampling designs to determine the spatial scales at which species and communities vary (e.g. Morrisey et al. 1992a, Lindegarth et al. 1995, Giménez \& Yannicelli 2000, Ollabaria \& Chapman 2001), but the relations between temporal and spatial variation in environmental variables (explanatory variables) and biological patterns and processes in macrobenthic assemblages are still poorly understood.

In this study we analyse regional and local distributional patterns of intertidal macrobenthic assemblages in the Westerschelde (The Netherlands) during the period 1994 to 2000 using a hierarchical sampling design. This approach provides a powerful framework for quantifying the proportion of the variation among samples that is attributable to each spatial or temporal scale. The dataset on which this study is based was collected as a baseline study to serve as a 'control' for the expected large-scale changes induced by the further deepening of the shipping channel to Antwerp. However, the study cannot be considered as a 'beforeimpact' study, since large-scale dredging in the Westerschelde has already been ongoing for decades. Between 1994 and 2000, 9.3-13.9 $\times 10^{6} \mathrm{~m}^{3}$ of sediment (mainly sand) was dredged yearly in the Westerschelde, with the major part of it being disposed back into adjacent gullies. Between July 1997 and July 1998 a further deepening took place. In the future a further deepening is planned. This will involve extensive dredging operations, and changes in current patterns, as well as in geomorphology of the estuary are anticipated.

The aim of our study was to quantify both the spatial and temporal variation in the abundance or biomass of benthic macrofauna species and assemblages in the intertidal zone of the estuary. More specifically, the study uses a hierarchical sampling programme to: (1) describe patterns in the distribution, abundance and biomass of macrobenthic species and assemblages over a variety of spatial scales; (2) calculate the relative amount of variability (magnitude of effects) encompassed at the different spatio-temporal scales based on variance components (Searle et al. 1992, Underwood 1997, Graham \& Edwards 2001); (3) identify the role of environmental variables in explaining the observed spatial and temporal variability in macrobenthic species abundance using multiple regression; (4) identify the role of environmental variables in explaining the observed variability in benthic macrofauna assemblage structure using canonical correspondence analysis with a forward selection method (ter Braak \& Verdonschot 1995); and (5) quantify spatial, temporal and environmentally structured variation in benthic macrofauna assemblage structure by using multivariate variance partitioning methods (Borcard et al. 1992, Franquet et al. 1995, Anderson \& Gribble 1998). We explicitly incorporated temporal variation among years, as most soft-sediment benthic studies have focussed solely on spatial scales (e.g. Jones et al. 1990, Morrisey et al. 1992a, Lindegarth et al. 1995), leaving the temporal variability in spatial patterns of both fauna and resources unknown (but see Morrisey et al. 1992b). Multiyear studies conducted at several spatial scales should provide the necessary background against which to offset possible changes due to human impacts on the estuarine ecosystem.

\section{MATERIALS AND METHODS}

Study area. The Schelde estuary (160 km long), a macrotidal, turbid, nutrient-rich, coastal plain estuary, is situated in NW Europe, near the border between The Netherlands and Belgium. The mean tidal range increases from $3.8 \mathrm{~m}$ near the mouth of the estuary to $>5.0 \mathrm{~m}$ upstream of the border. The river discharge varies from $20 \mathrm{~m}^{3} \mathrm{~s}^{-1}$ during summer to $600 \mathrm{~m}^{3} \mathrm{~s}^{-1}$ during winter, with a mean yearly average of $105 \mathrm{~m}^{3} \mathrm{~s}^{-1}$ (Baeyens et al. 1998). The residence time of the water in the estuary is rather high, ranging from $10-15 \mathrm{~d}$ in the most seaward region to $50-70 \mathrm{~d}$ in the regions 
upstream of the border, depending on the river discharge (Soetaert \& Herman 1995). The huge amount of respiration suggests a heterotrophic system (Heip et al. 1995). Indeed, annual gross bacterial production exceeds net primary production, even in the marine part, although the differences there become rather small (Goosen et al. 1999).

Sampling locations were situated in the downstream part of the estuary between the border and Vlissingen, the so-called Westerschelde (Fig. 1). This part of the estuary is well mixed and characterized by a complex network of flood and ebb channels surrounded by several large intertidal flats and marshes $(35 \%$ of the area). The study area comprises the polyhaline and mesohaline zones of the estuary.

Sampling design. Since 1994 a biological monitoring programme was set up as a baseline study to investigate the possible changes induced by a further deepening of the shipping channel to Antwerp. This programme was an extension of an ongoing programme investigating morphological (i.e. sedimentation/erosion) patterns at several locations/transects in the intertidal zone. The sampling design, although slightly unbalanced, was hierarchically scaled, covering 4 different spatial scales: region $\left(10^{4} \mathrm{~m}\right)$, transect $\left(10^{3} \mathrm{~m}\right)$, station $\left(10^{2} \mathrm{~m}\right)$, and replicate samples $\left(10^{-1} \mathrm{~m}\right)$ (Fig. 1). For the largest scale, the study area was divided into 3 regions, called West, Middle, and East. Within each region, 4 intertidal transects (3 in the western region) were placed randomly, each consisting of 3 (6 transects), 2 (4 transects) or 4 (1 transect) stations, resulting in a total of 30 stations being sampled. Each station was surveyed yearly in autumn (September-October) for benthic macrofauna. In 1996 station 406 was not sampled.
At each station 15 'small' replicates (sediment cores with $\varnothing 4.5 \mathrm{~cm}, 0.0239 \mathrm{~m}^{2}$ total surface) and 5 'large' replicates (sediment cores with $\varnothing 15 \mathrm{~cm}, 0.0884 \mathrm{~m}^{2}$ total surface) were taken. Small cores were fixed in the field with neutralised formaldehyde, brought to the laboratory and washed through a $1 \mathrm{~mm}$ mesh sieve. The large cores were washed in the field through a $1 \mathrm{~mm}$ mesh sieve and fixed with neutralised formaldehyde. In the laboratory the organisms of all samples were identified and counted. The large cores were used to obtain better abundance estimates of bivalve species and large polychaetes (species of the genera Arenicola, Glycera, Nephtys, Nereis, Scolelepis) and large arthropods (Carcinus, Crangon). For these species both small and large cores $\left(0.112 \mathrm{~m}^{2}\right.$ total surface $)$ were used for abundance and biomass estimates. Biomass values are expressed in $g$ ash free dry weight (g AFDW).

For bivalves regressions were established between length and AFDW, separately for each species, region and season. AFDW of a random sample of animals was determined by drying $\left(80^{\circ} \mathrm{C}\right.$ for a minimum of $\left.48 \mathrm{~h}\right)$ and ashing ( 560 to $580^{\circ} \mathrm{C}$ for $2 \mathrm{~h}$ ). Biomass of all other individuals was then calculated using this regression. For the other species, conversion factors between blotted wet weight (determined to the nearest $0.1 \mathrm{mg}$ ) and AFDW were established. These factors were again specific for species, region and season. After establishing the conversion factors, AFDW was calculated from the blotted wet weight of all individuals. Occasionally, for rare species, conversion factors for a morphologically similar species were used.

Environmental variables. Surface sediment samples (top $1 \mathrm{~cm}, \varnothing 2.0 \mathrm{~cm}$ ) were collected monthly for the analysis of chlorophyll $a(\mathrm{chl} a$ ). Each sample consisted

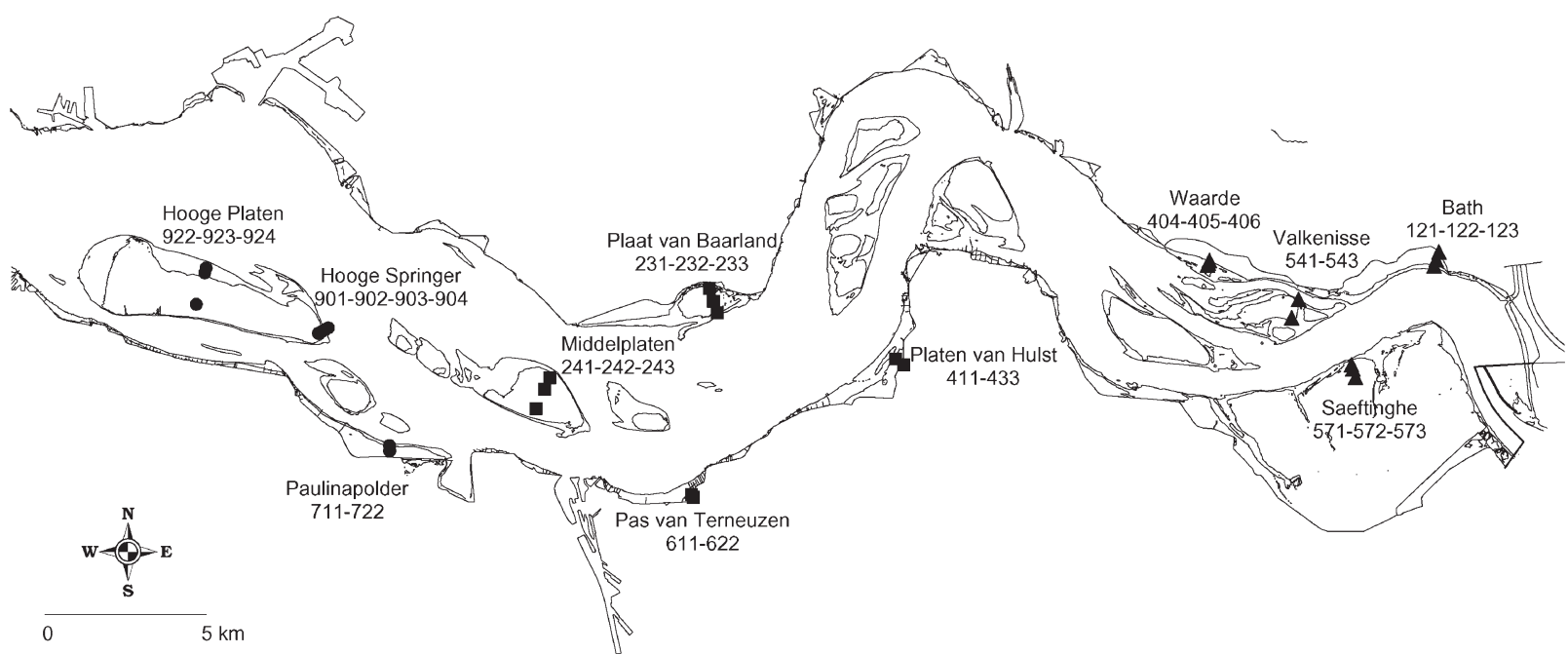

Fig. 1. Map of the Westerschelde (Dutch part of the Schelde estuary), showing transects (names) and stations (numbers). $\bullet:$ West region; $\mathbf{a}:$ Middle region; $\mathbf{\Delta}$ : East region 
of 5 randomly chosen subsamples. The mixed samples were directly frozen. Chl a was analysed by HPLC (Daemen 1986, De Jong \& De Jonge 1995), resulting in data expressed as $\mu \mathrm{g}$ chl a $\mathrm{g}^{-1}$ dry sediment $\left(\mu \mathrm{g} \mathrm{g}^{-1}\right)$. Since no data on bulk density of the sediment were available, conversion from $\mu \mathrm{g} \mathrm{chl} \mathrm{a} \mathrm{g}^{-1}$ dry sediment to $\mathrm{mg}$ chl a $\mathrm{m}^{-2}$ was not performed. For the area, De Jong \& De Jonge (1995) stated a multiplication factor of 15.5, based on an average bulk density of $1.55 \mathrm{~g} \mathrm{~cm}^{-3}$.

Sediment cores $(\varnothing 2.0 \mathrm{~cm})$ were taken to a depth of $2 \mathrm{~cm}(0-2 \mathrm{~cm}$ fraction) and $10 \mathrm{~cm}(0-10 \mathrm{~cm}$ fraction) respectively at each location in autumn of each year for sediment analysis (mud content [fraction $<63 \mu \mathrm{m}$ ] and median grain size). Each sample consisted of 2 subsamples. Sediment samples were analysed using a laser diffraction method (Malvern Mastersizer).

Morphological surveys were done approximately monthly at each station. Bed levels were measured at each station during mudflat exposure using a 'sedimentation-erosion' plot. This is a construction of 3 fixed poles forming a horizontal, triangular reference plane ( $1.5 \mathrm{~m}$ side). The exact height of the plot is known, and during each visit the distance from the top of the plot to the sediment surface is measured from a horizontal ruler, placed on top of the poles. Five measurements were taken at each side, resulting in 15 measurements for each plot. These 15 measurements were then averaged to give an average sediment surface elevation for each station. Bed level heights are expressed using the NAP (NAP: Dutch ordnance level, similar to mean sea level).

Monthly to fortnightly measurements at 7 monitoring locations along the Westerschelde were used for estimates of temporal variation in salinity. Salinity used in the analyses was determined as the average salinity of the period June to September for each year.

Current velocities (maximum or peak ebb and flood current velocities in $\mathrm{m} \mathrm{s}^{-1}$ ) for each station were estimated with the SCALDIS100 model (Dekker et al. 1994) for mean tidal conditions, with a spatial resolution of $100 \mathrm{~m}$.

Data analysis. For inter-annual comparisons, only those stations $(n=29)$ for which data where available for the complete study period were included.

Temporal changes in bed level height were expressed as long-term (1994 to 2000) trend ('longterm bed level elevation trend'), and a within-year trend for each of the years ('yearly bed level elevation trend'), based on the slope of a linear regression of height against time. Maximum difference in bed level height was calculated for each station as the range of observations for the whole study period and within a year. In order to link the within-year trend with sediment composition and benthic macrofauna, sampled in general in September, the period October to Septem- ber was considered to calculate the within-year trend. For chl $a$, yearly averaged values were used in all analyses.

Two-factor analysis of variance (ANOVA) without replication was used to test for differences between years and stations on mud content and chl a content. This analysis is allowed since the factors Year and Station are treated as random factors, but the analysis does not reveal measures of both interaction and error variability (Zar 1996). Temporal yearly patterns for mud content and chl a content were further examined based on standardized data. Standardization ( $z$-scores or standard scores) for each year within a station was achieved by subtracting the (long-term) station mean, $\mu$, from each yearly measurement $X_{i}$ and dividing by the station standard deviation $\sigma\left[z=\left(X_{i}-\mu\right) / \sigma\right]$. Standardization was achieved for each station separately; then the yearly average of the $z$-scores over the stations was calculated. To test for concordance between rank orders in years over stations, Kendall's $W$ statistic was calculated (Zar 1996). The value of $W$ may range from 0 (when there is no association) to 1 (when there is complete agreement among the ranking of all groups).

Hierarchical (nested) ANOVA was used to examine spatial and temporal variation in the distribution of macrofaunal total abundance, total biomass, and the abundance of the 11 most dominant taxa (referred to here as 'species', although one of them, oligochaeta, is actually a class). The objective was to identify the scales that contributed most to the variation in abundance or biomass. Both statistical significance and variance components (magnitude of effect) were estimated (Searle et al. 1992, Underwood 1997). The estimation of variance components is an important step in ecological analysis of variance, because variance components are the best estimate of the contribution of a given factor to variability in a response variable (Graham \& Edwards 2001). This can be achieved with a hierarchical sampling design, in which the different spatial and temporal scales are considered as random factors. The model contained factors (terms) representing the effects of Region, Transect nested in Region and Station nested in Transect and Region. The factor Year was added to the analysis, together with its interaction with Region, Transect and Station. Accordingly, the linear model becomes

$X=\mu+$ Region + Transect(Region) + Station(Region $\times$ Transect) + Year + Year $\times$ Region + Year $\times$ Tran$\operatorname{sect}($ Region $)+$ Year $\times$ Station $($ Region $\times$ Transect $)+\varepsilon$

where $\mu$ is the overall mean and $\varepsilon$ is the error term or residual. The residual is equivalent to the variation within each station (replicate samples).

The data were fitted to a random linear model using the general linear model (GLM) procedure of SAS (SAS software v8.02, SAS Institute Inc., Cary, NC). The 
F-test for each factor tests whether each level contributes significantly to the observed total variation. From the expected mean square estimates also a quantitative measure of the variation associated with each factor in the analysis was obtained, the so-called variance components (Searle et al. 1992, Underwood 1997). However, in the current situation, where the data were slightly unbalanced, standard ANOVA could not be applied to obtain estimates of the variance components. Hence, the residual maximum likelihood (REML) method available in the MIXED procedure of SAS was applied (Searle et al. 1992). REML analysis can be thought of as a generalisation of ANOVA.

Since data revealed non-normality and heterogeneity of variance in most cases, data were $\log (x+1)$ transformed prior to analysis. For Macoma balthica, Cerastoderma edule and Nereis (Hediste) diversicolor, analyses were based on the 5 large replicas; for the other species the 15 small replicas were used.

Multiple regression was used to identify the role of the measured environmental variables in explaining the observed spatial and temporal variability in macrobenthic species abundance or biomass. Therefore, we divided each environmental variable (mud content, median grain size, chl $a$, elevation, yearly bed level elevation trend, salinity) into 2 components: a spatial component and a temporal component. The spatial component consisted of the mean of a certain environmental variable at a certain station over the period 1994 to 2000, whereas the temporal component consisted of the deviance from this mean in each year. For maximum ebb and flood current velocity estimates only the spatial component was available, since these were model calculated estimates. As both sediment fractions $(0-2$ and $0-10 \mathrm{~cm})$ showed strong collinearity (see 'Results'), only the $0-2 \mathrm{~cm}$ was considered in the regression analysis. Mud content, median grain size, chl $a$ and current velocities were log-transformed prior to the analysis. A stepwise forward procedure was used in order to determine the subset of environmental variables that best explained the observed variation. Multiple regression was performed using the REG procedure of SAS.

Multivariate ordination techniques were applied to analyse the spatio-temporal variation in the species abundance data set, using the CANOCO 4.0 program (ter Braak \& Smilauer 1998). To remove any undue effects of rare species on the ordination analyses, species occurring at only 1 or 2 stations, with abundances $<100$ ind. $\mathrm{m}^{-2}$ (1 or 2 individuals observed), were excluded. Also taxa determined to family level or higher were excluded (except for Nemertea and Oligochaeta), and some taxa were grouped to genus level (Polydora, Eteone, Malacoceros, Anaitides). From 106 taxa, 33 remained for the gradient analyses, representing $99 \%$ of the total abundance. Species data were $\log (x+1)$ transformed prior to analysis.

'Regional' (analysis at the scale of regions, considering abundances pooled by region, i.e. 3 regions $x$ 7 years, $n=21$ ) and 'local' (analysis at the scale of the stations, i.e. 29 stations $\times 7$ years, $n=203$ ) principal patterns in species distributions were ordinated via (detrended) correspondence analysis [(D)CA], a widely used nonlinear eigenvector ordination technique. The 'arch effect' was apparent in the initial correspondence analysis based on the 'regions', suggesting the need for detrending.

For the 'local' analysis, the gradient length in standard deviation (SD) units, determined in a preliminary detrended correspondence analysis (DCA with detrending by segments), did exceed $3 \mathrm{SD}$, so subsequent numerical analyses involved techniques that were based on a underlying unimodal species-response model (Jongman et al. 1995, ter Braak \& Smilauer 1998). Statistical associations between assemblage patterns and environmental variables were further quantified via canonical correspondence analysis (CCA), a nonlinear eigenvector ordination technique related to $\mathrm{CA}$ but which constrains the axes to be linear combinations of the measured environmental variables (ter Braak 1986). A matrix of explanatory variables was constructed to determine the amount of variation in the species data that was related to changes in the abiotic environment. This matrix contained the following environmental variables: mud content, median grain size, chl $a$, bed level height, bed level elevation trend and maximum (yearly) difference in bed level height, maximum ebb and flood current velocity, and salinity.

Forward selection, an analogous procedure to the selection process in the stepwise multiple regressions, ordered the environmental variables according to the amount of variance they capture in the species data (ter Braak \& Verdonschot 1995). In the first step of this method, all environmental variables were ranked on the basis of the fit for each separate variable. Each variable was treated as the sole predictor variable, and all other variables were ignored; hence the variance explained represents marginal effects. At the end of the first step of the forward selection the best variable was selected. Hereafter, all remaining environmental variables were ranked on the basis of the fit (amount of variance explained) that each separate variable gives in conjunction with the variable(s) (covariables) already selected (conditional or unique effects). At each step, the statistical significance of the variable added was tested using a Monte Carlo permutation test (999 unrestricted permutations) (ter Braak \& Verdonschot 1995, ter Braak \& Smilauer 1998). Statistical significance of the first 4 axes and of the sum of all constrained eigenvalues of the CCA model was tested 
with a Monte Carlo permutation test (999 unrestricted permutations). Statistical significance of the second, third, and fourth axes was tested by carrying out partial analyses, where sample scores from the preceding axes were used as covariables (ter Braak \& Verdonschot 1995). Inter-set correlation of individual environmental variables with axes were examined to determine major environmental gradients in the ordination biplot. The species scores were scaled to be weighted averages of the station scores in the ordination plot.

The sampling design allowed us to strictly separate spatial and temporal patterns in the species data. Two matrices of explanatory variables were constructed to determine the amount of spatially and temporally structured variation in our data set. These matrices contained dummy variables (Jongman et al. 1995) for each station or each year respectively (Franquet et al. 1995). The amount of spatial (or temporal) variation in the data was assessed by running a CCA with all dummy variables for the stations (or years) as constraining variables. A series of partial CCA models was then used to decompose the variance in the response variables into independent components (method of variation partitioning, see Borcard et al. 1992, Økland \& Eilertsen 1994, Liu \& Bråkenhielm 1995). Partial CCA determines the variation explained by a set of explanatory variables that remains after the variation associated with another data set (covariables) have been removed. This variance partitioning allowed assessment of which part of the spatially or temporally structured variation could be explained by measured environmental variables (but it did not allow a test for the interactive effects between the spatial and temporal sources of variation). To reduce the possible effects of the difference in the number of variables included in each set of explanatory variables, we only used those variables that were significant based on a forward selection (Økland \& Eilertsen 1994). All the partial models were also tested using a Monte Carlo permutation approach.

The percentage of species variance explained by each CCA model was calculated as the ratio of the sum of the canonical eigenvalues of the CCA over the sum of the species matrix eigenvalues or total inertia (sum of all unconstrained eigenvalues of CA).

\section{RESULTS}

\section{Environment}

Mean height of the stations varied between $+2.32 \mathrm{~m}$ and -1.63 m NAP. Most stations (17) showed a general, significant decreasing trend in bed level height (erosion) in the period 1994 to 2000 (Table 1). Eleven sta- tions showed an increase in bed level height (sedimentation) in the same period, and only 1 station did not change significantly. Maximum difference in bed level height in the period 1994 to 2000 varied between a few $\mathrm{cm}$ and $>1 \mathrm{~m}$ (Table 1). The most irregular long-term pattern was observed at Stn 231, which showed very strong erosion until July 1996 (a decrease of $2615 \mathrm{~mm}$ ), after which strong sedimentation took place until March 1998 (an increase of 1710 mm). Individual transects showed different patterns, with all stations of a transect eroding, or all stations sedimenting, or a mix of these.

The sediment at most stations $(73 \%)$ consisted of fine sand, the remainder consisting of very fine sand (Table 1). Average mud content of the $0-2 \mathrm{~cm}$ fraction varied between 2 and $55 \%$. A significant negative correlation was observed between median grain size and mud content of the $0-2 \mathrm{~cm}$ fraction (log-transformed data, $\mathrm{n}=209$, Pearson's $\mathrm{r}=-0.86, \mathrm{p}<0.01$ ) and the 0-10 cm fraction (log-transformed data, $\mathrm{n}=209, \mathrm{r}=$ $-0.78, p<0.01$ ). Between the 2 fractions a strong positive correlation for median grain size was observed ( $\mathrm{n}=209, \mathrm{r}=0.80, \mathrm{p}<0.01$ ), whereas for mud content this correlation was weaker $(n=209, r=0.64, p<0.01)$. No relation with bed level height was observed. Mud content (fraction 0-2 cm) differed significantly between stations (2-way ANOVA, MS $=1.38, F_{28,168}=$ $19.0, \mathrm{p}<0.0001)$ and years (2-way ANOVA, MS = 0.32, $\left.F_{6,168}=4.34, \mathrm{p}<0.001\right)$. In general, mean mud content showed a slight decrease from 1994 to 1998, after which a slight increase was observed; but no similar temporal pattern between stations was observed (Kendall's $W$ statistic: 29 stations, 7 years, $W=0.08, \chi^{2}=$ $16.3, \mathrm{p}>0.05)$. Locally some clear annual trends were observed. Significant (linear) negative trends were observed at 8 locations, whereas only 2 locations showed a significant positive trend. Several stations showed a mixed pattern, with a decreasing trend followed by an increase (e.g. Stn 622, 406) or the opposite (e.g. Stn 922, 243, 404).

Highest bed level changes, indicated by high negative or positive 'bed level elevation trends' values, were only observed at low mud contents. In other words, strong sedimentation or erosion coincided mainly with low mud contents, whereas at high mud contents bed level changes were relatively small.

Yearly averaged chl a content varied substantially between stations (Table 1), showing a significant positive correlation with mud content (log-transformed data, $\mathrm{n}=209, \mathrm{r}=0.52, \mathrm{p}<0.01$ ) and a negative correlation with median grain size (log-transformed data, $\mathrm{n}=$ $209, \mathrm{r}=-0.41, \mathrm{p}<0.01)$. No relation with bed level height was observed. Chl a content differed significantly between stations (2-way ANOVA, MS = 243.7, $\left.F_{28,168}=54.8, \mathrm{p}<0.0001\right)$ and years (2-way ANOVA, 
Table 1. Mean bed level height (relative to NAP), number of observations, maximum difference in bed level height and 'longterm bed level elevation trend' (based on the slope of a linear regression of bed level height against time, with $\mathrm{R}^{2}$ and trend) for the period 1994 to 2000 at each station. For the position of transect names and station numbers, see Fig. 1. Trends: =, no significant trend $_{i}-$ or + , weak negative or positive trend (ranging from -0.05 to +0.05 ); -- or ++ , negative or positive trend (between -0.05 and -0.15 or between +0.05 and +0.15 respectively $)_{i}---$ or +++ , strong negative or positive trend $(<-0.15$ or $>0.15$ respectively $)$. Trend at Stn 231: see text. Mean sediment properties of each station based on the $0-2 \mathrm{~cm}$ fraction for the period 1994-2000 (1 autumn sample each year). Sediment types: VFS = very fine sand, median grain size between 63 and $125 \mu \mathrm{m}$; FS = fine sand 125 to $250 \mu \mathrm{m}$. Mud \% = fraction $<63 \mu \mathrm{m}$. Chl $a=$ mean of yearly averaged chlorophyll $a\left(\mu g \mathrm{~g}^{-1}\right.$ ) for the period 1994 to 2000 . Maximum ebb current velocity estimates $\left(\mathrm{m} \mathrm{s}^{-1}\right)$ were based on a 2D hydrodynamical model

\begin{tabular}{|c|c|c|c|c|c|c|c|c|c|c|c|}
\hline Transect & Stn & $\begin{array}{l}\text { Mean height } \\
\text { (mm NAP } \\
\pm \text { SD) }\end{array}$ & $\mathrm{N}$ & $\begin{array}{l}\text { Max. } \\
\text { difference } \\
(\mathrm{mm})\end{array}$ & $\begin{array}{l}\text { Elevation } \\
\text { trend }\end{array}$ & $\mathrm{R}^{2}$ & Trend S & $\begin{array}{l}\text { Sediment } \\
\text { type }\end{array}$ & $\begin{array}{l}\text { Mud \% } \\
\text { (mean } \\
\pm \mathrm{SD})\end{array}$ & $\begin{array}{l}\mathrm{Chl} \mathrm{a} \\
\text { (mean } \\
\pm \mathrm{SD})\end{array}$ & $\begin{array}{l}\text { Max. } \\
\text { ebb }\end{array}$ \\
\hline Hooge Platen (1) & $\begin{array}{l}922 \\
923 \\
924\end{array}$ & $\begin{array}{l}1308 \pm 43 \\
-169 \pm 85 \\
-511 \pm 128\end{array}$ & $\begin{array}{l}66 \\
64 \\
63\end{array}$ & $\begin{array}{l}177 \\
340 \\
517\end{array}$ & $\begin{array}{l}0.044 \\
0.101 \\
0.180\end{array}$ & $\begin{array}{l}0.52 \\
0.65 \\
0.90\end{array}$ & $\begin{array}{c}+ \\
+ \\
+ \\
+++\end{array}$ & $\begin{array}{l}\text { VFS } \\
\text { FS } \\
\text { FS }\end{array}$ & $\begin{array}{r}16.1 \pm 3.6 \\
10.2 \pm 5.2 \\
6.6 \pm 4.6\end{array}$ & $\begin{array}{l}7.2 \pm 1.50 \\
3.5 \pm 1.11 \\
3.1 \pm 0.83\end{array}$ & $\begin{array}{l}0.21 \\
0.58 \\
0.37\end{array}$ \\
\hline Hooge Springer (2) & $\begin{array}{l}901 \\
902 \\
903 \\
904\end{array}$ & $\begin{array}{r}1010 \pm 124 \\
944 \pm 170 \\
528 \pm 171 \\
-258 \pm 186\end{array}$ & $\begin{array}{l}72 \\
73 \\
72 \\
73\end{array}$ & $\begin{array}{l}492 \\
550 \\
698 \\
813\end{array}$ & $\begin{array}{l}-0.137 \\
-0.214 \\
-0.214 \\
-0.216\end{array}$ & $\begin{array}{l}0.72 \\
0.92 \\
0.92 \\
0.79\end{array}$ & $\begin{array}{l}-- \\
--- \\
--- \\
---\end{array}$ & $\begin{array}{l}\text { VFS } \\
\text { VFS } \\
\text { FS } \\
\text { FS }\end{array}$ & $\begin{array}{r}13.3 \pm 4.1 \\
11.7 \pm 4.5 \\
5.9 \pm 6.3 \\
2.9 \pm 2.0\end{array}$ & $\begin{array}{l}7.3 \pm 1.37 \\
6.2 \pm 2.18 \\
2.3 \pm 1.20 \\
1.2 \pm 0.47\end{array}$ & $\begin{array}{l}0.25 \\
0.22 \\
0.32 \\
0.28\end{array}$ \\
\hline Paulinapolder (3) & $\begin{array}{l}711 \\
722\end{array}$ & $\begin{array}{r}1228 \pm 62 \\
286 \pm 30\end{array}$ & $\begin{array}{l}74 \\
68\end{array}$ & $\begin{array}{l}212 \\
146\end{array}$ & $\begin{array}{l}0.078 \\
0.036\end{array}$ & $\begin{array}{l}0.82 \\
0.68\end{array}$ & $\begin{array}{c}++ \\
+\end{array}$ & $\begin{array}{l}\text { FS } \\
\text { VFS }\end{array}$ & $\begin{array}{r}5.5 \pm 2.4 \\
54.6 \pm 5.4\end{array}$ & $\begin{aligned} 10.6 & \pm 2.25 \\
9.0 & \pm 3.07\end{aligned}$ & $\begin{array}{l}0.15 \\
0.20\end{array}$ \\
\hline Middelplaten (4) & $\begin{array}{l}241 \\
242 \\
243\end{array}$ & $\begin{array}{r}1024 \pm 24 \\
938 \pm 35 \\
633 \pm 88\end{array}$ & $\begin{array}{l}72 \\
72 \\
72\end{array}$ & $\begin{array}{c}92 \\
145 \\
396\end{array}$ & $\begin{array}{l}-0.027 \\
-0.039 \\
-0.089\end{array}$ & $\begin{array}{l}0.67 \\
0.64 \\
0.54\end{array}$ & $\begin{array}{l}- \\
- \\
--\end{array}$ & $\begin{array}{l}\text { FS } \\
\text { FS } \\
\text { FS }\end{array}$ & $\begin{array}{l}2.4 \pm 1.0 \\
2.2 \pm 0.8 \\
2.5 \pm 1.6\end{array}$ & $\begin{array}{r}24.3 \pm 5.99 \\
11.2 \pm 3.01 \\
4.8 \pm 2.38\end{array}$ & $\begin{array}{l}0.27 \\
0.24 \\
0.22\end{array}$ \\
\hline Pas Terneuzen (5) & $\begin{array}{l}611 \\
622\end{array}$ & $\begin{array}{r}139 \pm 13 \\
-315 \pm 33\end{array}$ & $\begin{array}{l}72 \\
67\end{array}$ & $\begin{array}{c}59 \\
125\end{array}$ & $\begin{array}{r}0.015 \\
-0.042\end{array}$ & $\begin{array}{l}0.72 \\
0.72\end{array}$ & $\begin{array}{l}+ \\
-\end{array}$ & $\begin{array}{l}\text { FS } \\
\text { FS }\end{array}$ & $\begin{array}{l}12.6 \pm 6.0 \\
11.2 \pm 8.0\end{array}$ & $\begin{array}{l}1.7 \pm 0.94 \\
1.1 \pm 0.63\end{array}$ & $\begin{array}{l}0.11 \\
0.16\end{array}$ \\
\hline Rug v Baarland (6) & $\begin{array}{l}231 \\
232 \\
233\end{array}$ & $\begin{array}{c}364 \pm 484 \\
1880 \pm 51 \\
1167 \pm 256\end{array}$ & $\begin{array}{l}67 \\
72 \\
71\end{array}$ & $\begin{array}{c}2615 \\
215 \\
766\end{array}$ & $\begin{array}{r}-0.120 \\
-0.054 \\
0.320\end{array}$ & $\begin{array}{l}0.03 \\
0.59 \\
0.83\end{array}$ & $\begin{array}{c}---/+++ \\
-- \\
+++\end{array}$ & $\begin{array}{l}\text { FS } \\
\text { FS } \\
\text { FS }\end{array}$ & $\begin{array}{r}4.0 \pm 3.8 \\
9.4 \pm 7.8 \\
12.9 \pm 8.7\end{array}$ & $\begin{array}{r}2.6 \pm 0.90 \\
1.1 \pm 0.66 \\
17.3 \pm 5.55\end{array}$ & $\begin{array}{l}0.26 \\
0.21 \\
0.43\end{array}$ \\
\hline Platen v Hulst (7) & $\begin{array}{l}411 \\
433\end{array}$ & $\begin{array}{r}324 \pm 13 \\
-339 \pm 37\end{array}$ & $\begin{array}{l}70 \\
71\end{array}$ & $\begin{array}{c}56 \\
136\end{array}$ & $\begin{array}{r}-0.012 \\
0.044\end{array}$ & $\begin{array}{l}0.39 \\
0.69\end{array}$ & $\begin{array}{l}- \\
+\end{array}$ & $\begin{array}{l}\text { FS } \\
\text { VFS }\end{array}$ & $\begin{array}{l}11.6 \pm 4.7 \\
25.4 \pm 6.3\end{array}$ & $\begin{array}{l}7.1 \pm 1.98 \\
2.5 \pm 1.34\end{array}$ & $\begin{array}{l}0.15 \\
0.35\end{array}$ \\
\hline Waarde (8) & $\begin{array}{l}404 \\
405 \\
406\end{array}$ & $\begin{aligned}-999 & \pm 89 \\
-1625 & \pm 102 \\
-1540 & \pm 18\end{aligned}$ & $\begin{array}{l}76 \\
69 \\
73\end{array}$ & $\begin{array}{c}357 \\
350 \\
73\end{array}$ & $\begin{array}{l}-0.074 \\
-0.069 \\
-0.020\end{array}$ & $\begin{array}{l}0.38 \\
0.28 \\
0.69\end{array}$ & $\begin{array}{l}-- \\
-- \\
-\end{array}$ & $\begin{array}{l}\text { VFS } \\
\text { FS } \\
\text { FS }\end{array}$ & $\begin{array}{r}26.0 \pm 12.6 \\
9.5 \pm 18.4 \\
26.0 \pm 15.6\end{array}$ & $\begin{array}{l}0.8 \pm 0.34 \\
2.6 \pm 1.44 \\
5.2 \pm 1.39\end{array}$ & $\begin{array}{l}0.42 \\
0.56 \\
0.60\end{array}$ \\
\hline Valkenisse Oost (9) & $\begin{array}{l}541 \\
543\end{array}$ & $\begin{array}{l}323 \pm 118 \\
700 \pm 180\end{array}$ & $\begin{array}{l}74 \\
74\end{array}$ & $\begin{array}{l}391 \\
621\end{array}$ & $\begin{array}{l}0.152 \\
0.217\end{array}$ & $\begin{array}{l}0.96 \\
0.84\end{array}$ & $\begin{array}{l}+++ \\
+++\end{array}$ & $\begin{array}{l}\text { FS } \\
\text { FS }\end{array}$ & $\begin{aligned} 12.2 & \pm 10.0 \\
2.1 & \pm 0.9\end{aligned}$ & $\begin{array}{l}4.3 \pm 0.98 \\
3.0 \pm 1.17\end{array}$ & $\begin{array}{l}0.49 \\
0.69\end{array}$ \\
\hline Saeftinghe (10) & $\begin{array}{l}571 \\
572 \\
573\end{array}$ & $\begin{aligned} 2319 & \pm 40 \\
1288 & \pm 192 \\
352 & \pm 361\end{aligned}$ & $\begin{array}{l}71 \\
70 \\
68\end{array}$ & $\begin{array}{c}130 \\
871 \\
1108\end{array}$ & $\begin{array}{r}-0.041 \\
0.051 \\
-0.308\end{array}$ & $\begin{array}{l}0.62 \\
0.04 \\
0.42\end{array}$ & $\begin{array}{c}- \\
= \\
---\end{array}$ & $\begin{array}{l}\text { FS } \\
\text { FS } \\
\text { FS }\end{array}$ & $\begin{array}{l}3.6 \pm 1.5 \\
2.6 \pm 2.9 \\
2.0 \pm 1.5\end{array}$ & $\begin{array}{l}1.0 \pm 0.34 \\
1.4 \pm 1.23 \\
2.6 \pm 0.65\end{array}$ & $\begin{array}{l}0.20 \\
0.27 \\
0.33\end{array}$ \\
\hline Bath (11) & $\begin{array}{l}121 \\
122 \\
123\end{array}$ & $\begin{array}{r}1326 \pm 28 \\
787 \pm 26 \\
-1403 \pm 11\end{array}$ & $\begin{array}{l}73 \\
73 \\
72\end{array}$ & $\begin{array}{c}95 \\
100 \\
47\end{array}$ & $\begin{array}{r}0.035 \\
-0.034 \\
-0.007\end{array}$ & $\begin{array}{l}0.83 \\
0.84 \\
0.21\end{array}$ & $\begin{array}{l}+ \\
- \\
-\end{array}$ & $\begin{array}{l}\text { VFS } \\
\text { VFS } \\
\text { FS }\end{array}$ & $\begin{aligned} 53.3 & \pm 8.3 \\
34.7 & \pm 15.3 \\
5.8 & \pm 2.5\end{aligned}$ & $\begin{array}{l}19.5 \pm 5.27 \\
13.7 \pm 3.30 \\
11.7 \pm 4.08\end{array}$ & $\begin{array}{l}0.10 \\
0.10 \\
0.28\end{array}$ \\
\hline
\end{tabular}

MS $\left.=106.5, F_{6,168}=9.35, \mathrm{p}<0.0001\right)$. Chl a content showed a similar temporal pattern in the period 1994 to 2000 in all 3 regions: a decreasing trend in the period 1994 to 1996, followed by an increasing trend until 2000 (Fig. 2a). This was also confirmed by the trend in standardized values (Fig. 2b) and Kendall's $W$ statistic (29 stations, 7 years, $W=0.28, \chi^{2}=48.9, \mathrm{p}<0.001$ ), indicating similar (parallel) temporal patterns between stations.

The model calculated ebb and flood current velocities showed a mutual significant positive correlation ( $\mathrm{n}=30, \mathrm{r}=0.88, \mathrm{p}<0.01)$, and showed a significant negative correlation with mean chl $a(\mathrm{n}=30, \mathrm{r}=-0.76$, $\mathrm{p}<0.01)$ and mean bed level height $(\mathrm{n}=30, \mathrm{r}=-0.45$, $\mathrm{p}<0.05$ ). No relation with mud content or median grain size was observed.

\section{General characterization of the benthic macrofauna}

A total of 106 taxa were observed during the study period. Mean number of taxa per station varied between 6 and 19, with an average of 13.6 taxa. Mean total abundance and biomass and mean abundance of the 11 most dominant species are shown for each station in Fig. 3. These species represent on average $86 \%$ of the total abundance and $79 \%$ of the total biomass. In all 3 regions macrobenthic communities were numerically dominated by a few species, mainly surface deposit feeders (e.g. Pygospio elegans, Tharyx marioni, Corophium volutator) and sub-surface deposit feeders (e.g. Heteromastus filiformis and Oligochaeta). Their mean relative contribution to the total abundance in each region was comparable with former 

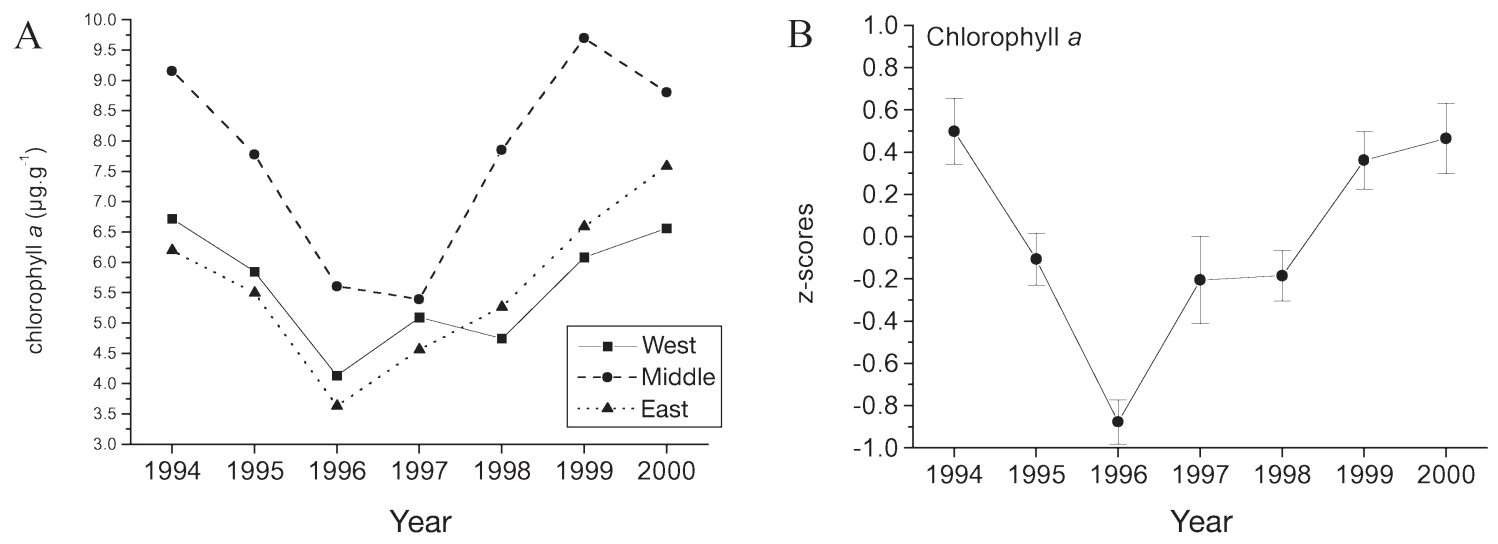

Fig. 2. (A) Mean chlorophyll a (chl a) content (yearly average) in the period 1994 to 2000 in the West, Middle and East region of the Schelde estuary. (B) Standardized chl a values ( $z$-scores \pm SE) in the period 1994 to 2000, based on all stations (n = 29)

studies on the intertidal benthic macrofauna of the Schelde estuary (e.g. Ysebaert et al. 1998, Ysebaert 2000). However, year-to-year variation was large for most species (Fig. 4), with some species showing very similar year-to-year patterns among regions (e.g. Macoma balthica and Scrobicularia plana).

As for abundance, few species dominated the community in terms of biomass in each salinity region, but dominance of feeding type differed among regions. In the western and middle region, the suspension feeder Cerastoderma edule was on average the most dominant species (30 to $35 \%$ of the total biomass), comparable with former studies (e.g. Ysebaert et al. 1998, Ysebaert 2000). However, large year-to-year fluctuations in biomass were observed for C. edule (Fig. 5), resulting in a relative contribution fluctuating between 16 and $53 \%$ and 19 and $72 \%$ in the West and Middle regions respectively. Despite the fact that the biomass of Heteromastus filiformis decreased substantially in the West and Middle part, its relative contribution did not change, but fluctuated between 10 and $19 \%$ and 7 and $20 \%$ respectively. In the eastern region Corophium volutator and $H$. filiformis dominated the biomass, but a clear opposite temporal pattern was observed for both species. High mean biomass values of $H$. filiformis coincided with low mean biomass values of $C$. volutator, which was reflected in their relative contribution to the total biomass. The pattern of $C$. volutator coincided very well with the pattern observed in mean chl a concentrations (yearly averaged) in the eastern region.

Although the extracted gradient in a DCA on regionally integrated data (analysis at the scale of the regions) was rather low $(<2 \mathrm{SD}$, conforming to a short ecological gradient), the ordination diagram was characterized by a distinct separation of the 3 regions along the first ordination axis (Fig. 6). The eigenvalue of the first axis $(0.15$, explaining $49 \%$ of the variance of species data) was relatively large compared with the second axis $(0.03$, explaining $10 \%$ of the variance of species data), suggesting that this gradient is by far the most important. The second axis seemed to be correlated with year, as indicated by the significant Spearman rank correlation $(r=0.70, p=0.001)$ of the ordination scores as a function of year.

\section{Spatio-temporal variation in benthic macrofauna species}

ANOVA components (Fig. 7) indicated different patterns for different species. Temporal variance components (factor Year and interaction between Year and spatial groupings) differed considerably between species. Especially for Oligochaeta, Tharyx marioni and Nereis diversicolor, the relative importance of the variance associated with time was very low, whereas it was highest for Scrobicularia plana, Corophium volutator and Pygospio elegans. For all species, except T. mari$o n i$, the factor Year $\times$ Station(Region $\times$ Transect) contributed significantly to the observed variability in abundance or biomass, and showed highest relative importance, indicating considerable differences in year-to-year variations between stations. However, Heteromastus filiformis, P. elegans, Macoma balthica, Cerastoderma edule, S. plana and total abundance displayed significant variability associated with the factor Year solely.

Variance associated solely with space was larger than the variance associated with time, but varied less, being 50 to $60 \%$ for most species; only for Nereis diversicolor, Oligochaeta and Tharyx marioni did this contribution increase to $>70 \%$. All species displayed significant spatial variability with the smallest scale 

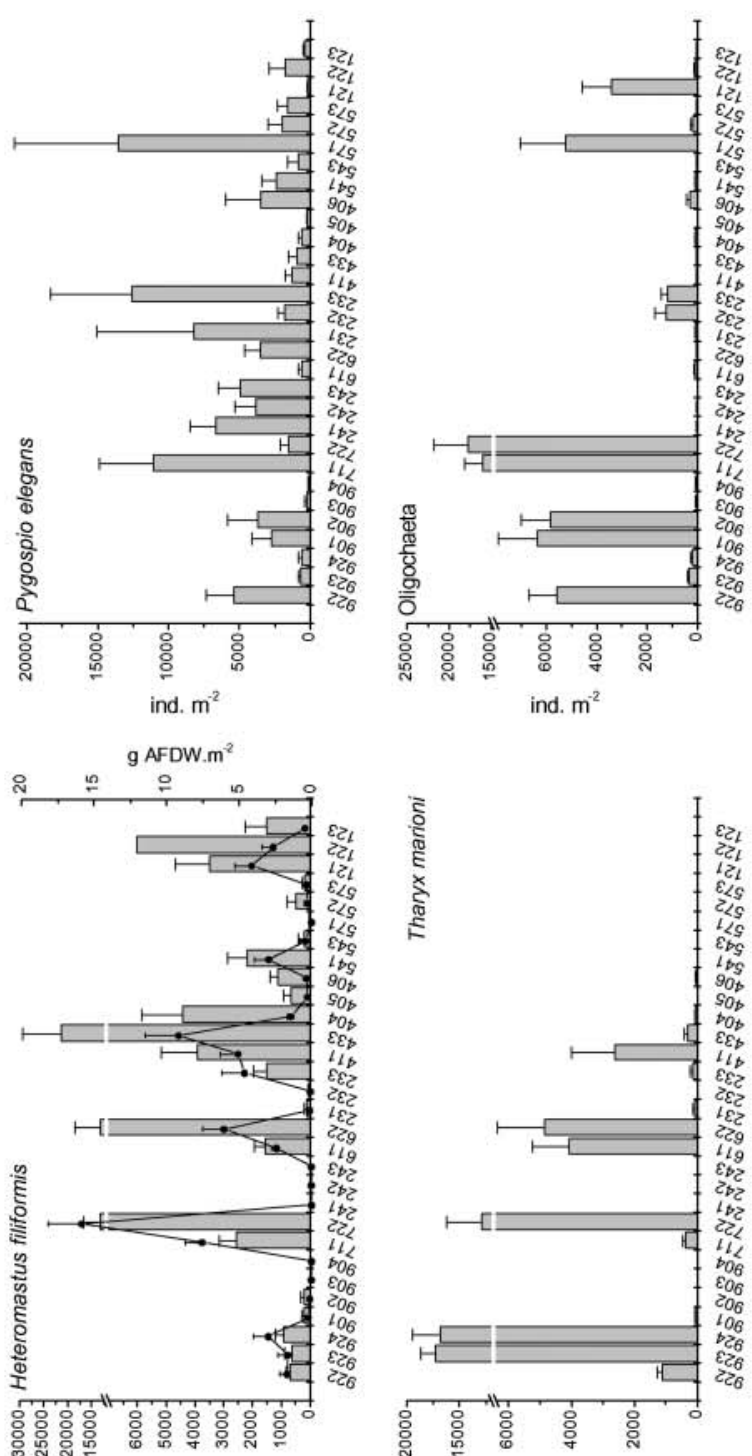

ind. $\mathrm{m}^{-2}$

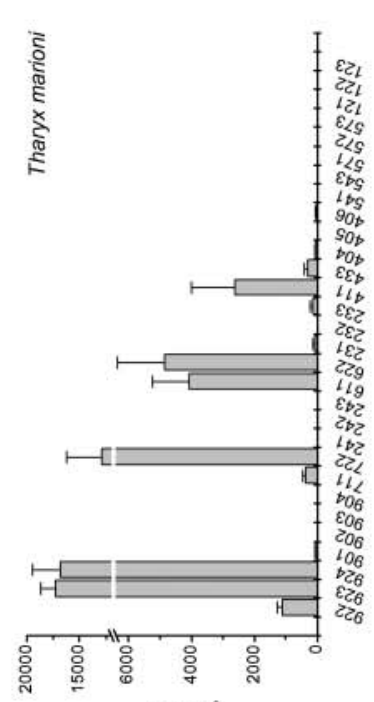

ind. $\mathrm{m}^{-2}$

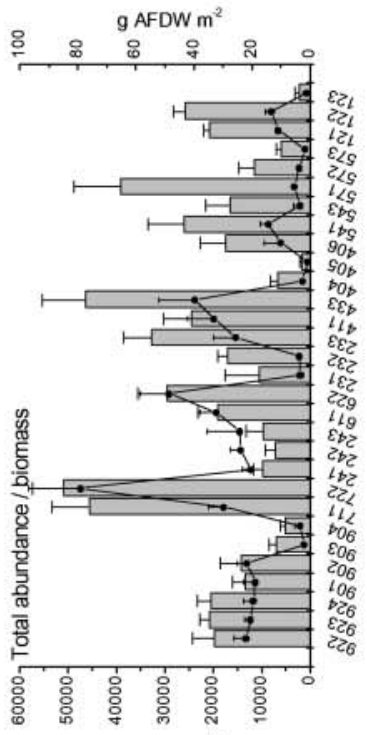

ind. $\mathrm{m}^{2}$

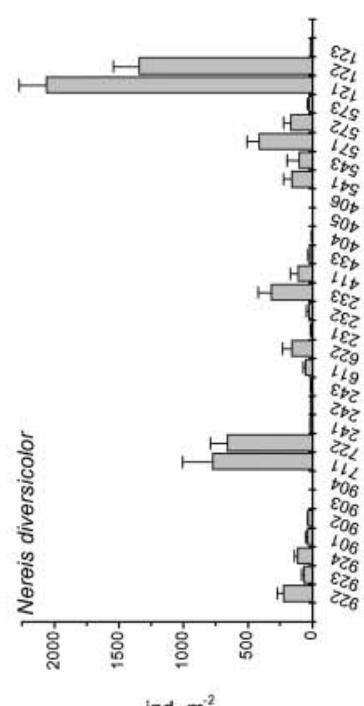

ind. $\mathrm{m}^{-2}$
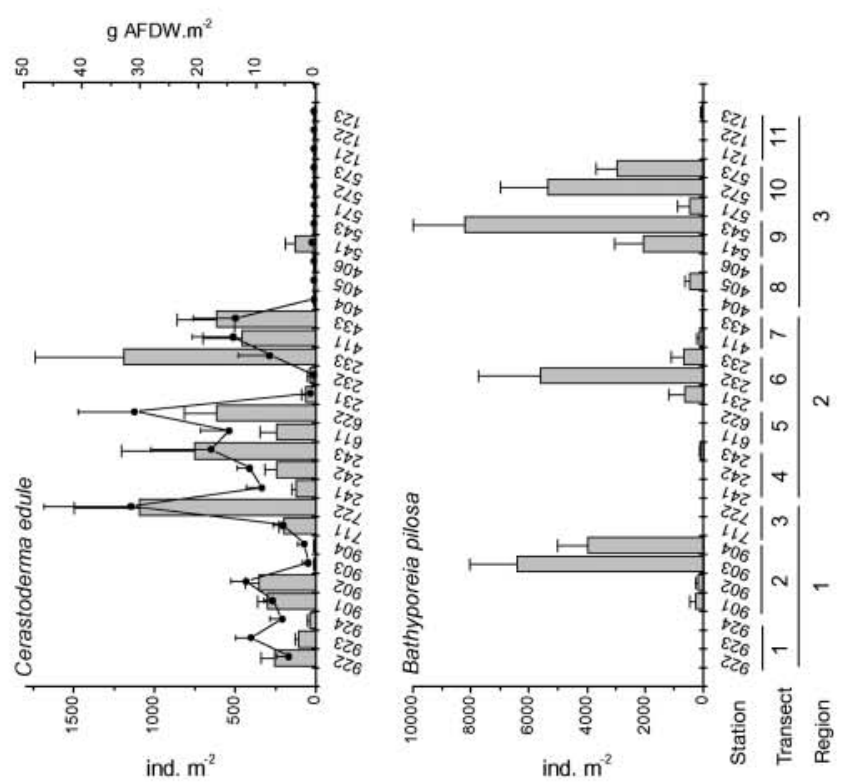

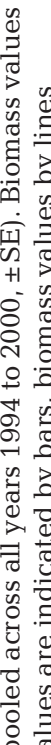

g AFDW $\mathrm{m}^{2}$
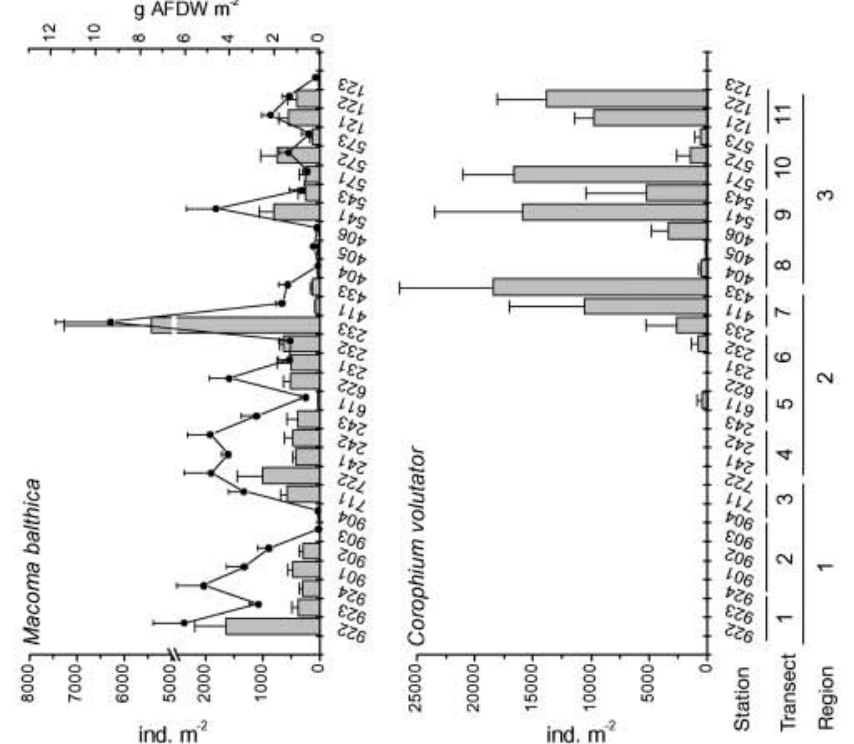

a.

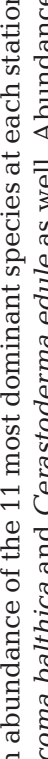

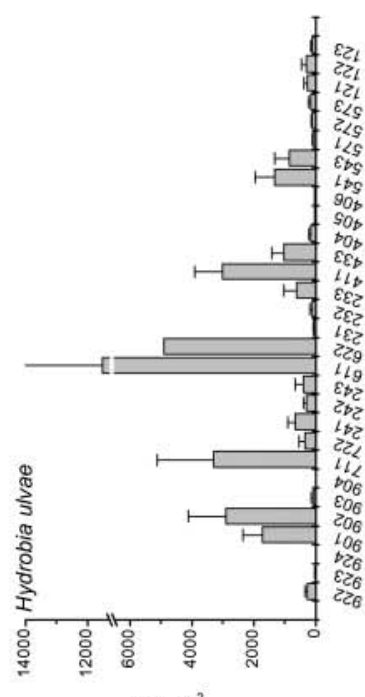

ind. $\mathrm{m}^{-2}$

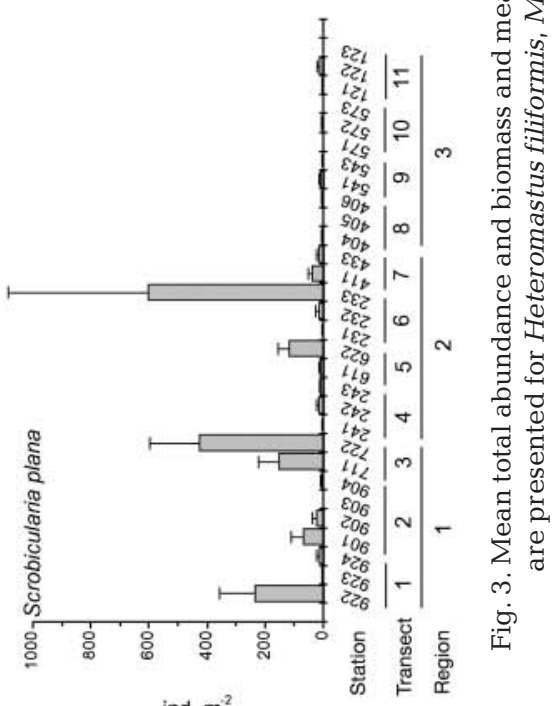

ind. $\mathrm{m}^{2}$ 

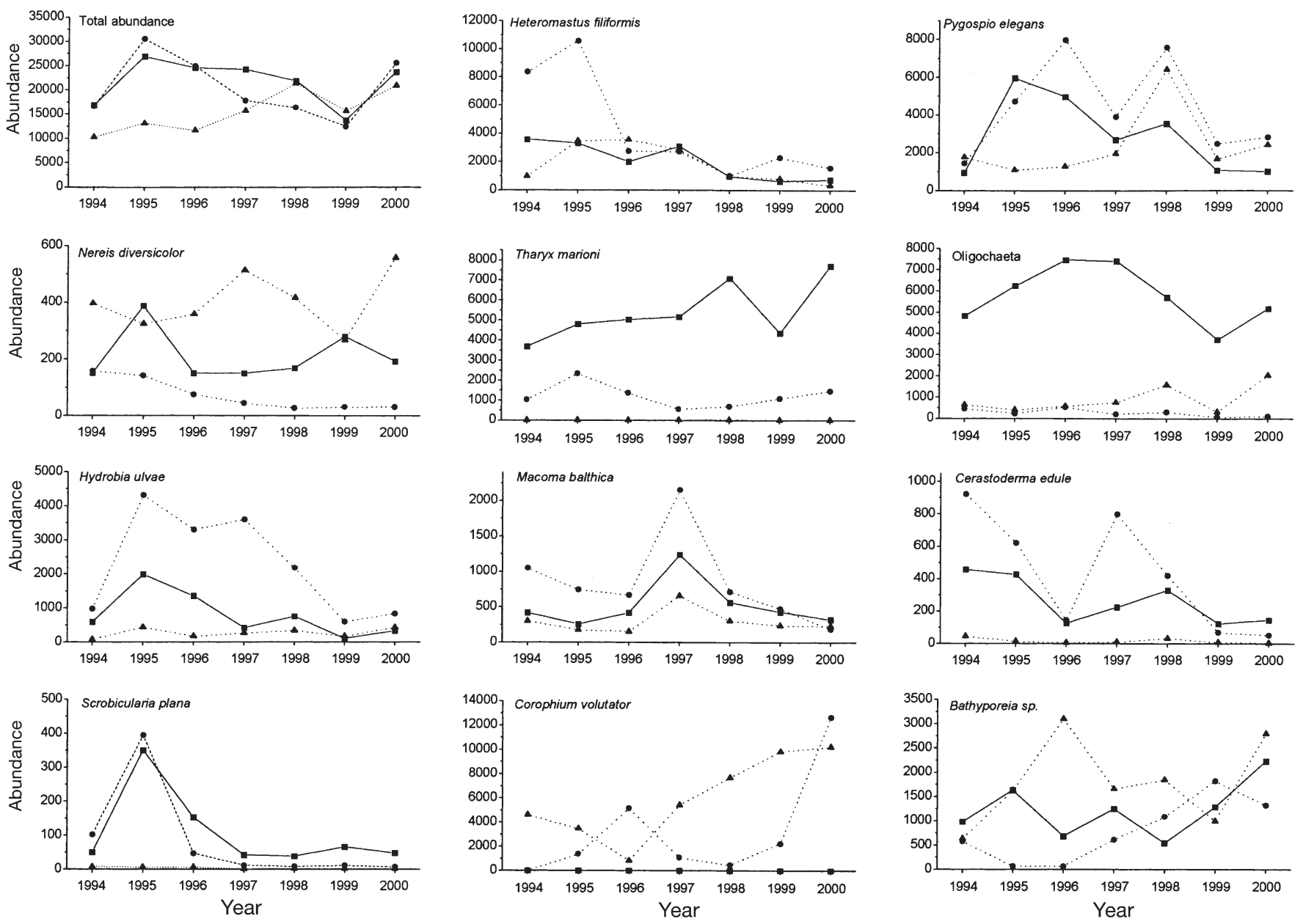

\section{- West ….......... Middle …....... East}

Fig. 4. Plots of mean total abundance (ind. $\mathrm{m}^{-2}$ ) and mean abundance (ind. $\mathrm{m}^{-2}$ ) of the 11 most dominant macrobenthic species in each region (West-Middle-East) over time (period 1994 to 2000)
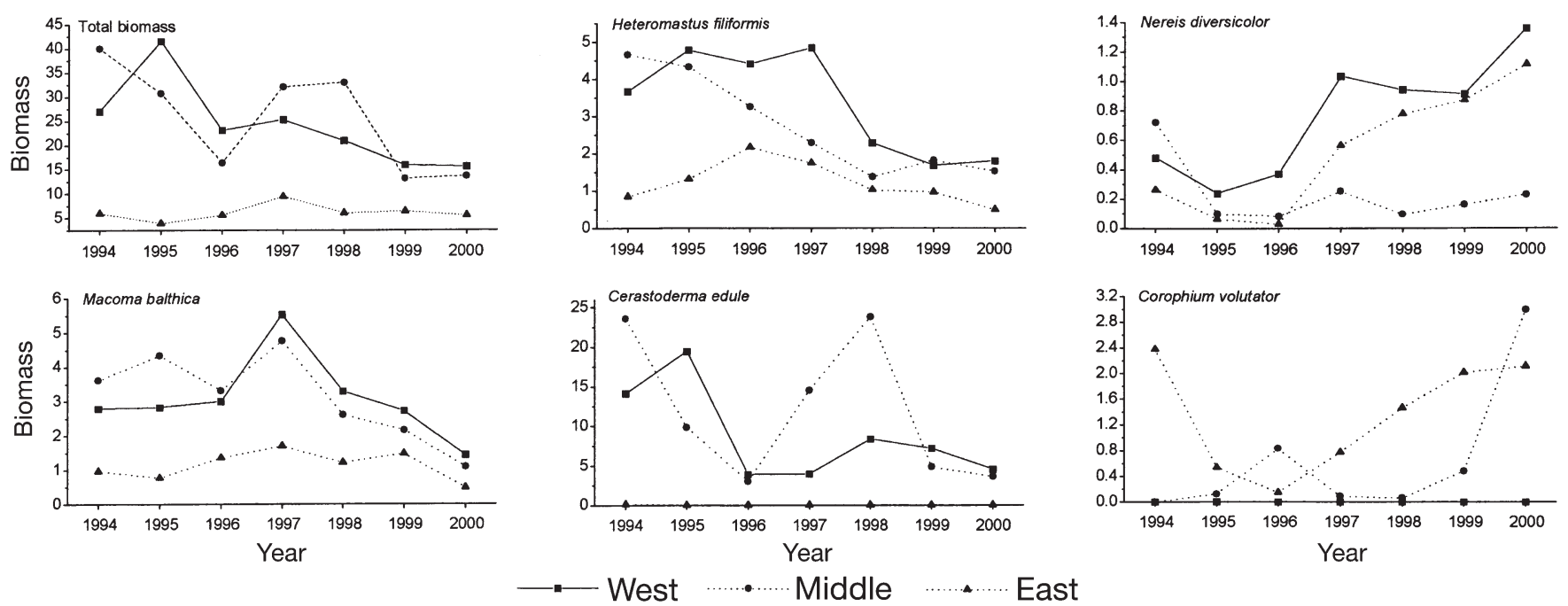

Fig. 5. Plots of mean total biomass $\left(\mathrm{g} A F D W \mathrm{~m}^{-2}\right.$ ) and mean biomass $\left(\mathrm{g}\right.$ AFDW m $\mathrm{m}^{-2}$ ) of the 5 most dominant macrobenthic species in each region (West-Middle-East) over time (period 1994 to 2000) 
considered [factor Station (Region $\times$ Transect)], indicating high variability among stations. As a consequence, for most species the relative contribution of this factor to the total variance was high. There were more significant differences at the smaller spatial scale than at the larger spatial scales. Significant differences at the transect scale [factor Transect(Region)] were observed for only 5 species, but the relative contribution to the total variance was for some species larger than the smaller spatial scale, indicating differences between transects larger than those between stations (e.g. for Heteromastus filiformis, T. marioni and Hydrobia ulvae). At the largest spatial scale (factor Region), only significant differences were observed for $T$. marioni, Oligochaeta and Cerastoderma edule. Contribution to the total variance was relatively high for $C$. edule, Oligochaeta and total biomass. For several species the factor Region was completely of no importance

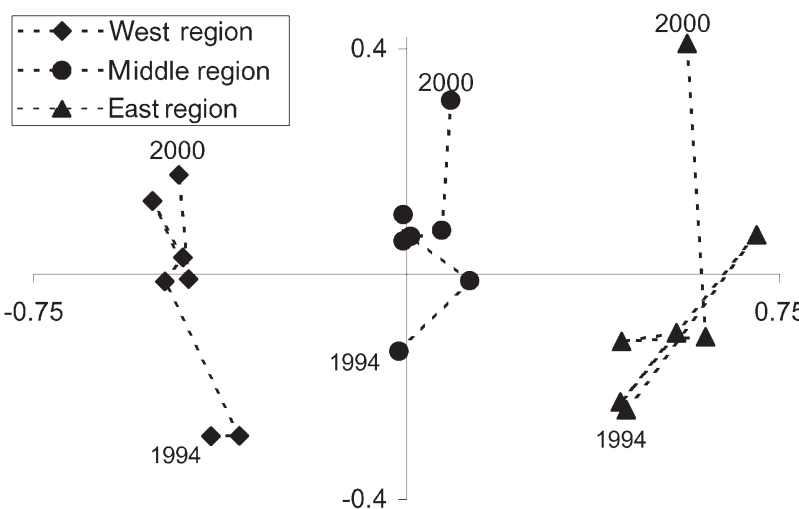

Fig. 6. Detrended correspondence analysis (DCA) ordination plot for macrobenthic species abudance data showing region scores for the period 1994 to 2000. For each region, a line connects scores for each successive year to facilitate the interpretation of temporal succession in the ordination diagram. Detrending was performed using second-order polynomials
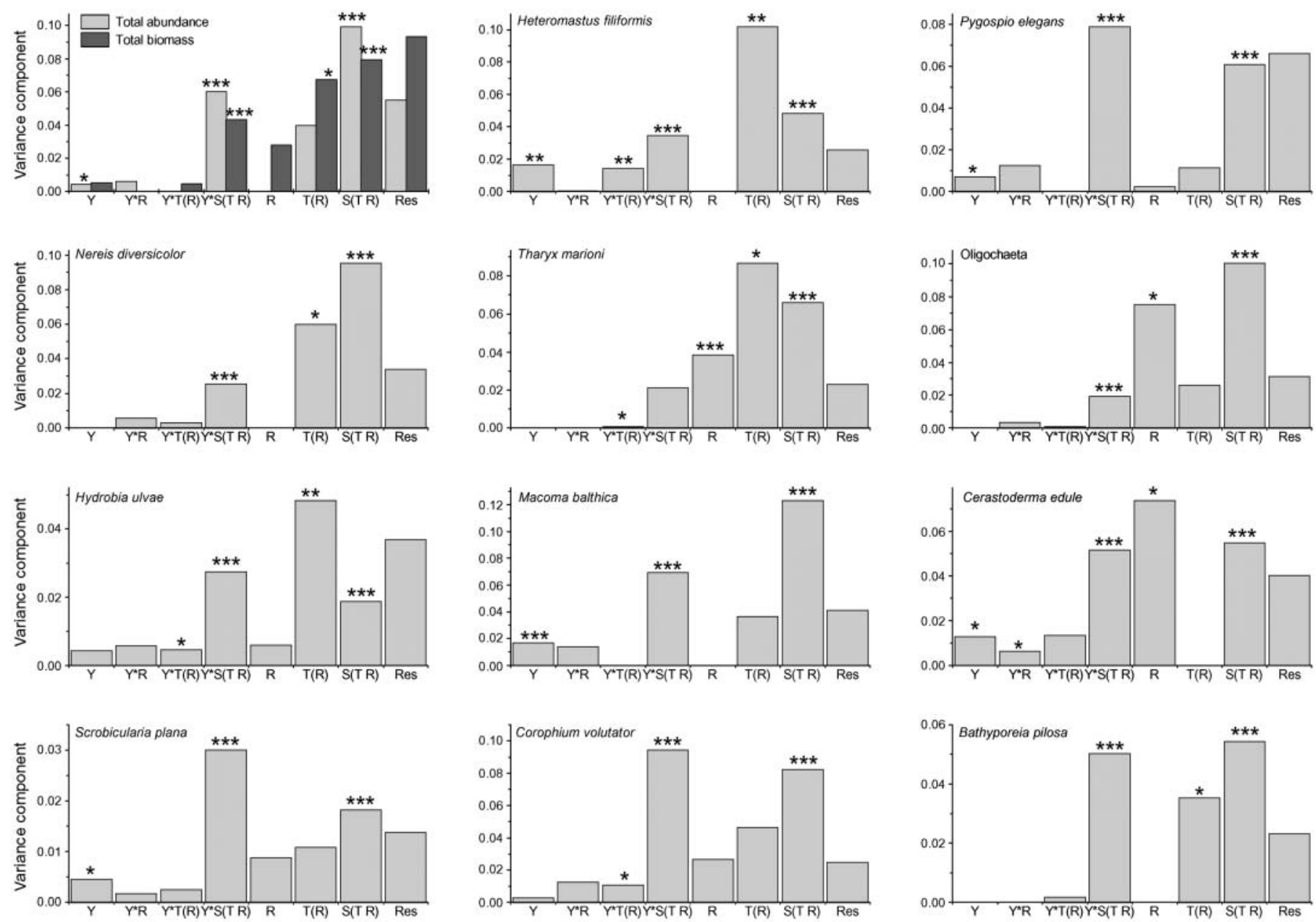

Fig. 7. Variance components for total abundance, total biomass and abundance of the 11 most dominant species. Factors are: $\mathrm{Y}=$ Year; $\mathrm{Y}^{*} \mathrm{R}=$ Year $\times$ Region; $\mathrm{Y}^{*} \mathrm{~T}(\mathrm{R})=$ Year $\times$ Transect $\left(\right.$ Region) $; \mathrm{Y}^{*} \mathrm{~S}(\mathrm{~T} \mathrm{R})=$ Year $\times$ Station $($ Transect $\times$ Region) $; \mathrm{R}=\mathrm{Region} ;$ $\mathrm{T}(\mathrm{R})=$ Transect(Region); $\mathrm{S}(\mathrm{T} \mathrm{R})=$ Station(Transect $\times$ Region); Res = residual. ${ }^{*}$ Scales of significant variation from the nested ANOVA analyses: ${ }^{*} \mathrm{p}<0.05,{ }^{* *} \mathrm{p}<0.01,{ }^{* *} \mathrm{p}<0.001$ 

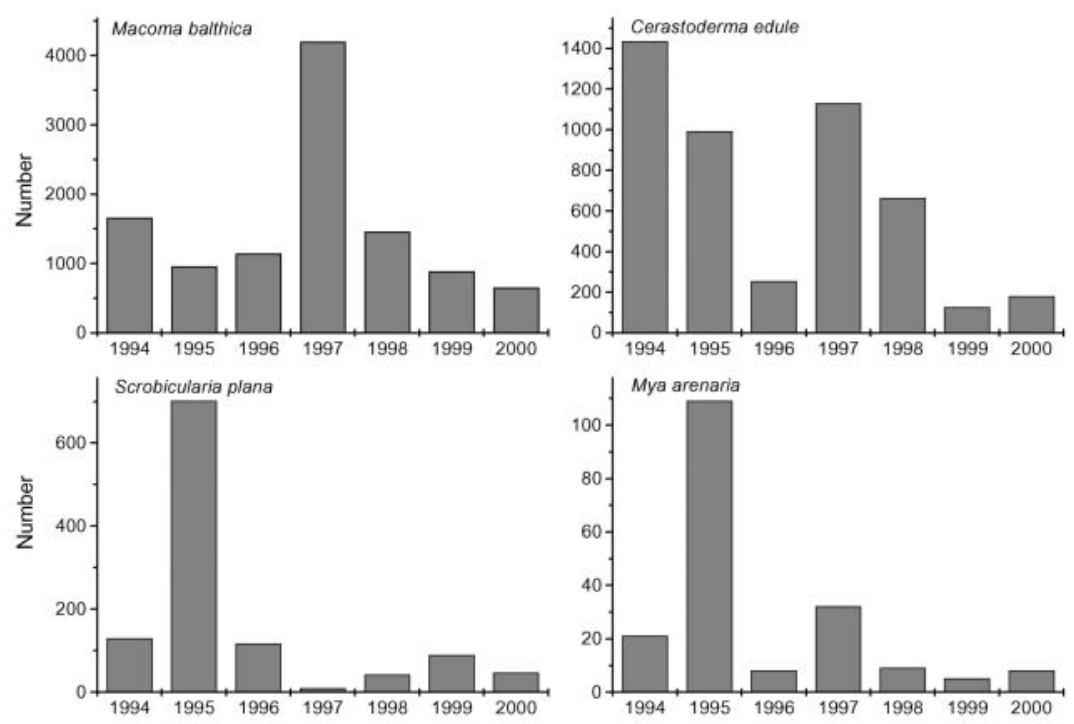

Fig. 8. Number of bivalve recruits observed yearly in autumn for the period 1994 to 2000 (sum of all locations). The following length ranges were used to identify recruits: Macoma balthica: $0-7 \mathrm{~mm}$; Cerastoderma edule: 0-10 mm; Scrobicularia plana: 0-18 mm; Mya arenaria: 0-8 mm

\section{Role of environmental variables in explaining observed spatio-temporal variations}

\author{
Univariate analyses: multiple \\ regression analyses
}

A multiple regression using the environmental variables, divided into 'spatial' (average) and 'temporal' (residual) components, as independent variables and macrobenthic species abundance or total abundance/biomass as response variables, revealed models explaining between 27 and $56 \%$ of the variance in species abundances and explaining 57 and $45 \%$ of the variance in total biomass and total abundance respectively (Table 2). The stepwise procedure showed that variation was mainly explained by the 'spatial' components of the environmental variables. For most macrobenthic species, local environmental variables, especially mud content, chl $a$ and bed level height, explained the largest part of the observed variation. Mud (H. filiformis, N. diversicolor, Macoma balthica and Bathyporeia pilosa).

Both spatial and temporal components explained $>80 \%$ (maximum of $92 \%$ ) of the total variance for most species; only for Pygospio elegans, Hydrobia ulvae, total abundance and total biomass was this somewhat lower $(70$ to $80 \%)$. The remaining unexplained variance (the error term or residual) is the within-station variation. This suggests that patchiness exists at smaller spatial scales than station.

For bivalve species, observed trends were to a great extent determined by their (successful) recruitment patterns (Fig. 8). New recruits of Macoma balthica were observed yearly in autumn samples, with a distinct peak in autumn 1997 (following the severe winter of 1996/97). The yearly pattern is very similar to that observed for the total abundance pattern of this species in each region (Fig. 5). For Cerastoderma edule, high numbers of new recruits were observed in 1994, 1995, 1997 and 1998, and this pattern was very similar to the total abundance pattern of this species in the Middle region, where it was most abundant. Scrobicularia plana only showed a relatively high number of new recruits in 1995, mainly in the West region. After 1995, hardly any new recruits were observed, resulting in a decreasing trend in abundance and biomass. In the East region Mya arenaria showed successful spatfall in 1995 (similar as to S. plana), and to a lesser extent in 1994 and 1997. All bivalve species showed very low numbers in 1999 and 2000. content explained a large part of the observed variation for the sub-surface deposit feeder Heteromastus filiformis (positive correlation), whereas bed level height explained most part of the variation for Oligochaeta and the surface deposit feeders Macoma balthica, Pygospio elegans and Nereis diversicolor. The grazer Hydrobia ulvae showed a strong positive relation with chl a. For $H$. filiformis, Oligochaeta and Tharyx marioni, mud content and median grain size showed both a positive relationship, although both environmental variables were mutually strongly negatively correlated. This phenomenon could be explained by the fact that those species prefer muddy sediments, but with a relatively large amount of sand in it. Bathyporeia pilosa showed a different pattern, having a strongly negative relation with chl $a$, which is explained by the fact that this species prefers more dynamic, sandy sediments. For some species (e.g. T. marioni, C. edule, Corophium volutator) salinity explained a large part of the observed variation, which was consistent with the results of the variance components (importance of factor Region). A clear difference in the environmental variables explaining the variation in total biomass and total abundance was observed; chl $a$ and salinity explained a large part of the observed variation in total biomass, whereas mud content and height explained that for total abundance. This is a reflection of the differences in species dominance that determines total abundance and biomass. A significant positive contribution of 'bed level elevation trend' was 
also noticed for both total biomass and abundance, indicating higher abundance and biomass values in environments subject to sedimentation than in those subject to erosion. This was not noticed for all individual species, except for T. marioni and H. ulvae.

The 'temporal' (residual) components explained no significant variation for several macrobenthic species. If included, they only explained a small part of the variation. However, for some species a relationship was observed with (residual) chl $a$, being negative for Heteromastus filiformis and positive for the surface deposit feeders Macoma balthica, Pygospio elegans, Corophium volutator. This is consistent with the higher abundances of the latter species in years with higher chl a contents. Positive relationships between (residual) mud content and $H$. filiformis, $P$. elegans and Nereis diversicolor indicated higher abundances of these species in years with higher mud contents. The opposite was observed for Bathyporeia pilosa.

\section{Multivariate analyses: (partial) CCA with forward selection}

CCA of species abundance data with stepwise forward selection of environmental variables retained 7 environmental variables (Table 3). It produced an ordination in which the first 4 axes were statistically significant ( $p<0.01)$, with eigenvalues of $0.19,0.17,0.08$ and 0.04 respectively. Yearly bed level elevation trend and maximum difference in bed level height were removed from the CCA model. Both removed variables also had very low marginal effects, with only the maximum difference in bed level height having a significant marginal effect $(\mathrm{p}<$ 0.004 ), explaining $1.8 \%$ of the variation in the species data. The forward selection showed that salinity and mud content, and to a lesser extent also bed level height and chl $a$, explained best the variance in the species data (conditional effects) (Table 3). Together, the 7 selected variables explained $29 \%$ of the variation in the species data, which was $97 \%$ of the total variance explained from the original 9 variables. The percentage of variance explained by

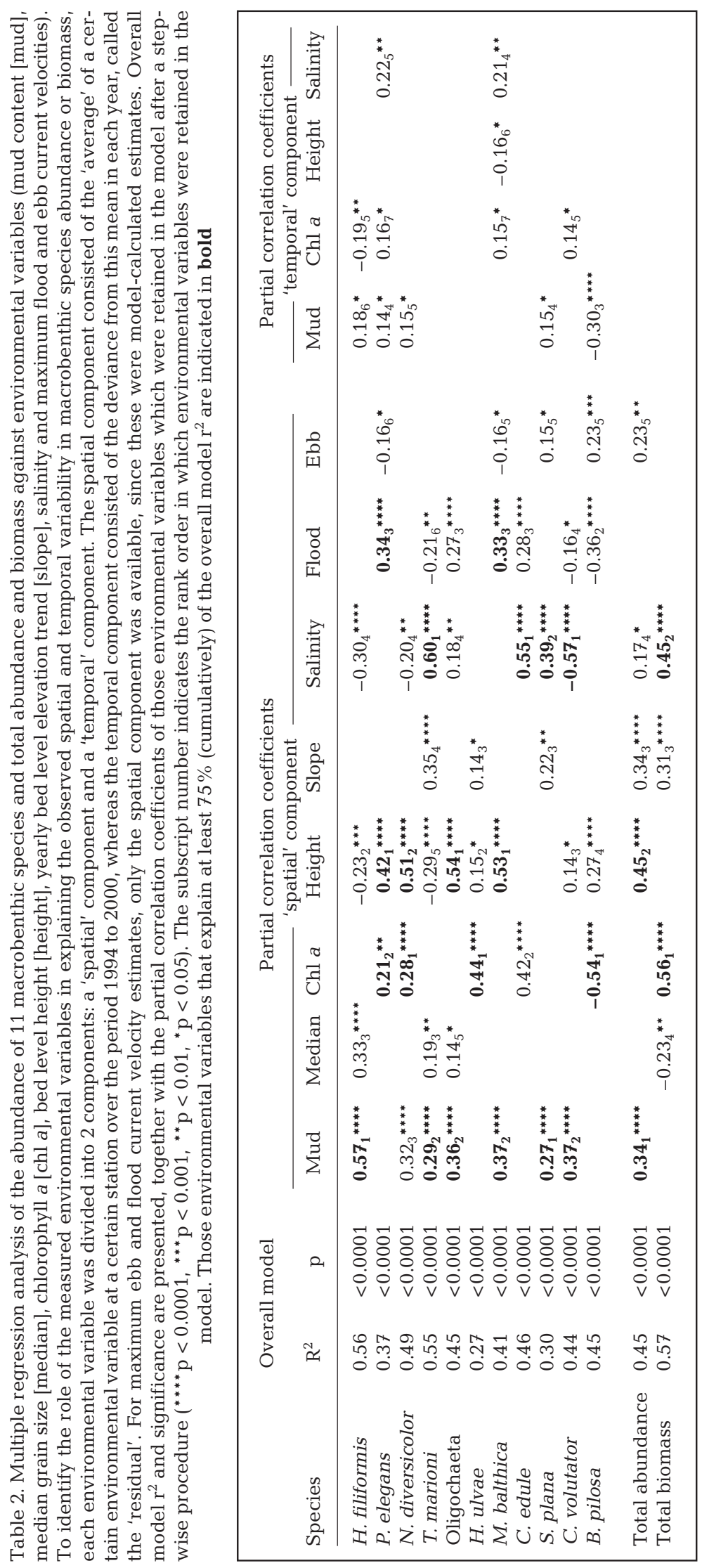




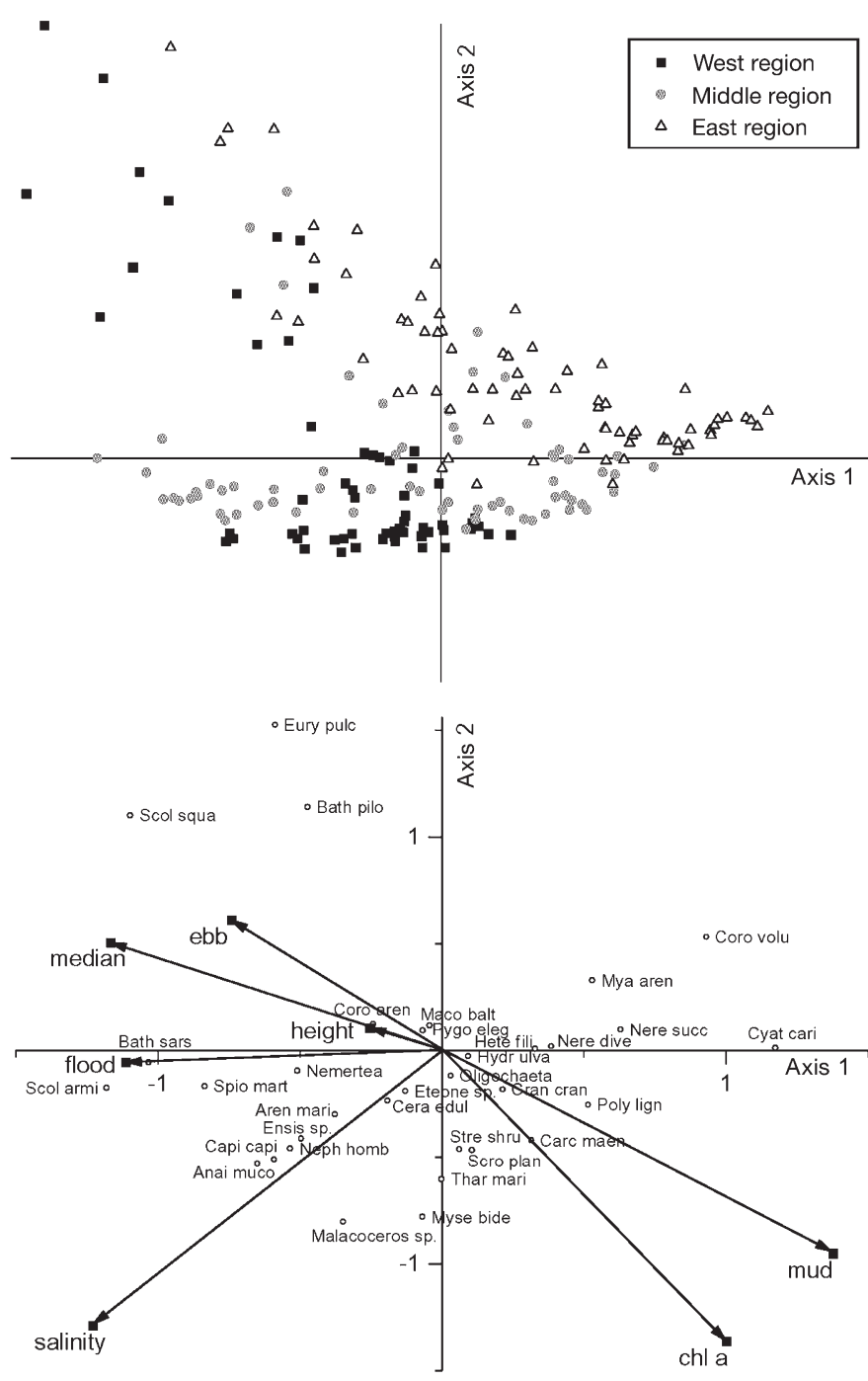

Fig. 9. Canonical correspondence analysis (CCA) ordination diagrams for macrobenthic species abundance data. For results on the CCA analysis see Table 3. (A) Sample scores for each region along the first and second axes. (B) Species scores along the first and second axes in relation to environmental variables (mud, mud content; median, median grain size; ebb and flood, maximum ebb and flood current velocities; height, bed level height; chl $a$, chl $a$ content). The environmental variables are shown as arrows, the lengths of which indicate the relative importance and the directions of which are obtained from the correlation of the variable to the axes. The orthogonal projection of a species point onto an environmental arrow represents the approximate center of the species distribution along that particular environmental gradient. Species are indicated with the first 4 letters of their genus and species name respectively. Arthropoda: Bathyporeia pilosa, Bathyporeia sarsi, Carcinus maenas, Corophium arenarium, Crangon crangon, Cyathura carinata, Eurydice pulchra; Mollusca: Cerastoderma edule, Ensis sp., Hydrobia ulvae, Macoma balthica, Mya arenaria, Mysella bidentata, Scrobicularia plana; Annelida: Anaitides mucosa, Arenicola marina, Capitella capitata, Eteone sp., Heteromastus filiformis, Malacoceros sp., Nephtys hombergii, Nereis diversicolor, Nereis succinea, Oligochaeta, Polydora sp., Pygospio elegans, Scolelepis squamata, Scoloplos armiger, Spio martinensis, Streblospio shrubsolii, Tharyx marioni each environmental variable as the sole predictor variable (marginal effects) was largest for salinity (9\%), mud content $(8 \%)$ and chl a $(8 \%)$, followed by bed level height (5\%) and median grain size (5\%).

Environmental variables correlated with the first CCA axis described a gradient from samples with high mud content and lower current velocities at the positive end to samples characterized by higher current velocities and lower mud content at the negative end (Table 3, Fig. 9). The second axis showed highest correlation with chl a content, but the direction and magnitude of this variable was very similar with that of mud content. As such, a clear discrimination between species related to more sandy sediments with a low chl a content (e.g. Eurydice pulchra, Bathyporeia pilosa and Scolelepis squamata) and species related to more muddy sediments with a higher chl a biomass (e.g. Cyathura carinata, Nereis succinea, Corophium volutator and Polydora sp.) was observed in the ordination biplot. The first and second axes were also determined to a large extent by salinity. Macrobenthic species characteristic of the polyhaline zone of the estuary (e.g. Scoloplos armiger, Anaitides mucosa, Spio martinensis) were situated in the lower left-hand side of the ordination biplot, whereas typically mesohaline species (e.g. C. volutator, C. carinata) were situated in the upper right-hand side of the biplot. The third CCA axis was strongly correlated with bed level height.

A series of (partial) constrained ordinations allowed us to partition the variation in the species data into spatial, temporal and environmental components. Spatial variation in the data set amounted to $56.7 \%$ of the total species variation (Table 4 ). About half of this variation can be explained by the set of explanatory environmental variables used. Only $4.1 \%$ of the species variation is temporally structured, and none of this is explained by the set of explanatory environmental variables. This small contribution of temporally structured variation seems to be in agreement with the results of the multiple regressions, for which also small contributions of the 'temporal' component in explaining the total variance were noticed. A separate CCA (not presented), using the same subdivision of the environmental variables into a long-term average and a temporal component as used in the multiple regression, showed also that the long-term averages were much more important than the yearly deviations from this average.

\section{DISCUSSION}

Different methods exist to describe the scale dependence of variation in biological data. They can broadly be divided into grid-sampling approaches describing 
Table 3. Results of canonical correspondence analysis (CCA) for macrobenthic species abundance data based on the 29 stations for the period 1994 to $2000(n=203)$. Inter-set correlations between the first 3 canonical axes and environmental variables are presented. Marginal effects denote percentage variance explained (percentage of the total variance in the species data explained) by using each environmental variable as the sole predictor variable. Conditional (unique) effects denote variance explained by each environmental variable with the variable(s) already selected treated as covariable(s) based on forward selection. Environmental variables are listed by the order of their inclusion in the forward-selection model. Significance levels are based on a Monte Carlo permutation test with 999 unrestricted permutations

\begin{tabular}{|c|c|c|c|c|c|}
\hline $\mathrm{CCA}$ & Axis 1 & Axis 2 & Axis 3 & & \\
\hline Eigenvalue & 0.19 & 0.17 & 0.08 & & \\
\hline Species-environment correlation & 0.85 & 0.75 & 0.80 & & \\
\hline \multicolumn{6}{|l|}{ Cumulative \% variance } \\
\hline Of species data & 10.9 & 20.5 & 25.1 & & \\
\hline Of species-environment relation & 36.2 & 68.4 & 83.3 & & \\
\hline \multirow[t]{2}{*}{ Environmental variable } & \multicolumn{3}{|c|}{ Inter-set correlations with } & Marginal effects & Conditional effects \\
\hline & Axis 1 & Axis 2 & Axis 3 & & \\
\hline Salinity & -0.52 & -0.48 & 0.10 & $9 \%(p<0.001)$ & $(\mathrm{p}<0.001)$ \\
\hline Mud content & 0.59 & -0.36 & -0.02 & $8 \%(p<0.001)$ & $8 \%(17 \%)(p<0.001)$ \\
\hline Bed level height & -0.11 & 0.04 & -0.77 & $5 \%(\mathrm{p}<0.001)$ & $4 \%(21 \%)(p<0.001)$ \\
\hline Chl a & 0.43 & -0.51 & -0.06 & $8 \%(p<0.001)$ & $4 \%(25 \%)(p<0.001)$ \\
\hline Maximum flood current velocity & -0.47 & -0.02 & 0.09 & $4 \%(\mathrm{p}<0.001)$ & $2 \%(27 \%)(p<0.001)$ \\
\hline Median grain size & -0.50 & 0.19 & 0.08 & $5 \%(\mathrm{p}<0.001)$ & $1 \%(28 \%)(p<0.001)$ \\
\hline Maximum ebb current velocity & -0.32 & 0.23 & 0.22 & $4 \%(p<0.001)$ & $1 \%(29 \%)(p<0.002)$ \\
\hline
\end{tabular}

the structure of spatial autocorrelation and hierarchical sampling approaches (e.g. nested ANOVA) (Ellis \& Schneider 1997, Cole et al. 2001). Dealing with a largescale study with irregular spatial intervals, we here used a hierarchical approach to reveal macrobenthic distribution and abundance/biomass patterns at different spatio-temporal scales in an estuarine, intertidal soft-sediment environment. Within this general class of methods, our study included several possible approaches to the problem. We have used univariate ANOVA-based analyses for the dominant species, and multivariate analyses (CCA) for the species-assemblage structure. We have also confronted a variance- decomposition approach with regression-based models describing the dependence of assemblage patterns on environmental variables. Our approach has also explicitly addressed the problem of interacting spatial and temporal variation.

As such, our study is one of the first to use this suite of methods for soft-sediment benthic macrofauna distributions along estuarine gradients. In other marine environments, such as subtidal soft sediments (Morrisey et al. 1992a), coasts (Lindegarth et al. 1995, Lawrie \& McQuaid 2001), rocky shores (Archambault \& Bourget 1996, Benedetti-Cecchi 2001, Hutchinson \& Williams 2001), and coral reefs and lagoons (e.g. Jones

Table 4. Result of the different (partial) constrained ordinations, indicating the contribution of spatial, temporal and environmentally structured variation to the total variation in the data set

\begin{tabular}{|lrll|}
\hline Variation accounted for in species data & $\%$ & & Method of calculation \\
\hline All variation & 100.0 & $(1)$ & CA on species matrix (unconstrained) \\
Environmental variation & 30.0 & $(2)$ & CCA on species matrix constrained by environmental matrix \\
Spatially structured variation & 56.7 & $(3)$ & CCA on species matrix constrained by spatial matrix \\
Temporally structured variation & 4.1 & $(4)$ & CCA on species matrix constrained by temporal matrix \\
Non-spatially structured environmental & 3.1 & $(5)$ & Partial CCA on species matrix constrained by environmental \\
variation & & & matrix with spatial matrix as covariables \\
Non-temporally structured environmental & 29.4 & $(6)$ & Partial CCA on species matrix constrained by \\
variation & & & environmental matrix with temporal matrix as covariables \\
Spatially structured environmental variation & 26.9 & $(7)$ & $(2)-(5)$ \\
Temporally structured environmental variation & 0.6 & $(8)$ & $(2)-(6)$ \\
Non-spatially or temporally structured & 2.5 & $(9)$ & $(2)-(7)-(8)$ \\
environmental variation & & & $100-(3)-(4)-(9)$ \\
Unexplained variation & 36.7 & & \\
\end{tabular}


et al. 1990, Hughes et al. 1999), spatial variation was also studied using nested, hierarchical sampling designs, but few of these studies examined the different sources of variation (spatial, temporal, environmental) simultaneously.

In our study spatial variability was studied in more detail as temporal variability, considering only between-year variation for the temporal component. As a consequence, we lack more fine-scale (within-year) temporal variability, for which probably a higher temporal variability would have been found, due to the large seasonal fluctuations in macrobenthic soft-sediment populations (Ysebaert 2000). However, multiyear studies conducted at several spatial scales should provide the necessary background from which to offset possible changes due to changed forcing of the system.

\section{Large-scale variations}

The comparison of large-scale variation has yielded 2 interesting contrasts between the univariate and multivariate analyses. For the spatial component, i.e. variation among the 3 'regions', only a few of the univariate analyses revealed a significant variance component. This was the case for Cerastoderma edule, Tharyx marioni and Oligochaeta, but for none of the other species studied. For Scrobicularia plana and Corophium volutator the contribution of Region was relatively large, although not significant. The Year $\times$ Region interaction was only significant for $C$. edule. The most obvious explanation for regional differences is the salinity gradient along the estuarine axis, and this indeed was the best correlating factor in the multiple regression, at least for $C$. edule, T. marioni and $C$. volutator. For Oligochaeta the correlation was considerably weaker, due to the nonlinearity of their response to salinity (their abundance was lowest in the intermediate region). However, it is remarkable that all other dominant species showed little dependence on salinity, reflected either in the importance of the regional component in their variance or in the linear regression analysis. In contrast to this, inter-regional differences were clear in the multivariate analyses, both in the DCA and the CCA. Community composition and the occurrence of rarer species (e.g. Cyathura carinata with preference for the mesohaline zone, and Scoloplos armiger for the polyhaline zone) discriminated better between the regions than did the abundance of most of the common species.

In the case of temporal variation between years, there was a number of dominant species showing significant synchronicity in temporal development between stations. This was indicated by the significance of the Year component in the variance for the molluscs
Macoma balthica, Cerastoderma edule and Scrobicularia plana, but also, surprisingly, for the polychaetes Heteromastus filiformis and Pygospio elegans (although also significant interaction with Station was noticed). Climatic factors can synchronise population changes over wide geographical areas if they have a direct effect on recruitment or mortality. Several species, bivalves in particular, show highly successful recruitment during the summer following a cold winter (Beukema et al. 1996, 2001). For other species, e.g. the predatory polychaete Nephtys hombergii, severe winters cause mass mortality, and the population density is determined by the recovery cycle in the following years (Beukema et al. 2000). These authors also describe cascading effects of the predator density on 2 of its main prey populations. During the 7 yr observation period, only 2 winters (1995/96 and 1996/97) were really cold, with $>10 \mathrm{~d}$ showing freezing temperatures all day. Especially in the severe winter of 1996/97 the cold period was relatively long, causing mud and sand flats to be frozen or ice-covered. The other winters ranged from very mild to normal, with $<5 \mathrm{~d}$ with freezing temperatures all day. Only Macoma balthica showed an enhanced recruitment success in autumn 1997, following the severe winter of 1996/97. C. edule also showed high numbers of recruits in autumn 1997, but this was the case in 1994, 1995 and 1998 as well. $S$. plana showed no enhanced recruitment due to preceding severe winters; it only showed enhanced recruitment in 1995. A similar pattern was observed for Mya arenaria, although a small peak was observed in 1997. The severe winter of 1995/96 seemed not to have any effect on the recruitment success of bivalves.

Summarizing, the magnitude of recruitment was extremely variable between years, and rarely showed co-variation between different species within a given year. The potential causes and consequences of this variability, in conjunction with spatial scale, probably vary on a species-to-species basis. Beukema et al. (2001) remarked that the effect of severe winters, which is very clear in the Wadden Sea, seems to disappear rapidly when going southward. Our study area has average winter temperatures about $2^{\circ} \mathrm{C}$ higher than the Wadden Sea, and this difference seems to be important in that critical lower temperatures are reached much less frequently. When comparing the strength of recruitment of several species in our study to that in the Wadden Sea for the same years, we could not discover any apparent synchronicity.

Synchronous evolutions in the polychaetes Heteromastus filiformis and Pygospio elegans in our study could not be related to the density of an infaunal predator. Especially for $H$. filiformis, however, it seemed to depend (negatively) on $\mathrm{chl}$ a levels in the sediment. The species was especially abundant in years when 
$\mathrm{chl}$ a levels were rather low and grazing species (e.g. Corophium volutator) were less abundant.

In contrast to what was the case for spatial patterns, the multivariate analysis revealed only very little temporally structured variation in the assemblage structure. None of this structure could be related to the measured environmental variables. It seems unlikely that cascading effects from the dominant species on the rest of the assemblage was an important structuring mechanism.

\section{Intermediate-scale variations}

For some species, the 'transect' scale contributed significantly to the variance of the density. This was particularly the case for Heteromastus filiformis, Tharyx marioni and Hydrobia ulvae, for which it was the largest variance component. Significant Year $\times$ Transect components, indicating synchronous development among transects, were also found for these 3 species. It is not very clear what factor caused populations in stations on the same transect to be more similar to each other than to those on other transects. It cannot be explained by environmental factors, since the 3 species differ in their relative dependence on environmental variables, and, moreover, the transects usually show quite variable habitat types. Possibly short-distance dispersal of adults (in the case of $H$. ulvae) or egg capsules in the case of the polychaetes causes homogenisation of the population densities over probable distances of displacement.

\section{Small-scale (100 to $500 \mathrm{~m})$ variations}

For most species variations at the scale of stations, and Year $\times$ Station interactions were the most important components of variability. With only 1 exception (Year $\times$ Station in Tharyx marioni), these components were significant when compared to the residual within-station variation. Other studies on the patchiness of invertebrates in sediments also observed considerable variation at small spatial scales. Morrisey et al. (1992a), using a hierarchical sampling design for the distribution of major taxa in subtidal sediments, showed significant spatial variation at scales ranging from $10 \mathrm{~m}$ to $3.5 \mathrm{~km}$, but the pattern of differences at various spatial scales differed among taxonomic groups. Kendall \& Widdicombe (1999) observed macrobenthic assemblages to be homogeneous at scales from $50 \mathrm{~cm}$ to $500 \mathrm{~m}$ in fine-sand sediments, whereas heterogeneity was apparent at distances $>50 \mathrm{~m}$ in muddier sediments. Patterns of heterogeneity on a scale of between 5 and $30 \mathrm{~m}$ were observed for several polychaete and mollusc species on an intertidal flat in Manukau Harbour (New Zealand) by Thrush et al. (1989). Patchiness at even smaller scales $(\mathrm{cm})$ were observed for the distribution of polychaetes in soft sediments by Volckaert (1987). All these studies investigated patchiness at smaller spatial scales than our study, suggesting that heterogeneity exists at scales smaller than those considered in our study. In our study, the remaining unexplained variance (withinstation variation) suggests also that variation exists at smaller spatial scales than station. It can be concluded that non-random variations at the level of the station dominate the patterns observed in our estuarine macrobenthic assemblages.

It is consistent with this observation that a substantial part of the total variation, both in density of individual species and in composition of the assemblage (as revealed in the multivariate studies), can be explained by the observed environmental variables. The species composition of the assemblage and the abundance of the individual species are dependent on the abiotic characteristics of (mostly) the station. This is consistent with observations on an intertidal flat in Manukau Harbour (Thrush et al. 1997a), where spatial distribution of macrofauna at larger scales (hundreds of meters) appeared to be more related to physical factors (topography, current shear stress, wind stress) (Legendre et al. 1997), whereas at scales of meters adult-larva interactions seemed to be an important factor producing patches of macrofauna (Turner et al. 1997). Thrush et al. (1997b) concluded that different processes operate at different spatial scales and that processes operating at small scales can influence large-scale patterns.

In this dependence on environmental variables, there is a large difference between the spatial and temporal component of variation in the environment. Subdivision of the environmental variables into a longterm average and a temporal component always shows that the long-term averages were much more important than the short-term deviations from this average. Also in the multivariate analysis, only spatially structured environmental variation explained a significant part of the variation, but there was no role at all for temporally structured environmental variation. In addition, the directly observed short-term variations in bed level height, indicative of erosion-deposition processes, did not explain any variation at all in any species. We conclude, therefore, that species adapt to local (10 to $100 \mathrm{~m}$ scale) average conditions, but are relatively insensitive to short-term or very small-scale variations in their environment.

One possible methodological explanation for this observation is the lack of within-year replication in most of the environmental variables. Therefore the observed residuals from the long-term average condi- 
tions mix 3 sources of variation: true temporal deviations, small-scale (within-station) spatial variation and random sampling error. If the latter 2 components would dominate, little relation could be expected with the species abundances. Proper replication of environmental variables, comparable to the set-up of the species monitoring, is a necessary complement to the sampling design used here.

There are, however, good biological reasons to expect that sampling variation is not the only reason for the observed unimportance of the temporal component in the environmental variables. Most of the species studied have long ( $\geq 1 \mathrm{yr}$ ) life-cycles with only 1 recruitment peak per year. Compensatory adaptation to relatively short-term temporal variations in the environment seems a prerequisite for them to survive in the intrinsically variable estuarine environment. Moreover, the dependence of the species on the environmental variables may be indirect through biological interactions. Beukema et al. (2000) document the dependence of Heteromastus filiformis and Scoloplos armiger on cold winters through the population development of their-cold-sensitive-predator Nephtys hombergii. Flach (1992) illustrated the importance of biotic interactions between Arenicola marina and Corophium volutator to explain the dependence of the latter species on the mud content of the sediment. Important in these interactions is the time lag involved in population responses, which should therefore lead to adapted assemblage structures at a time scale of several years, but are not expected to allow the assemblage to immediately adapt to short-term variations in the environment.

\section{Implications for monitoring programmes}

Our results have a number of implications for the design of monitoring programmes for large-scale impacts on the estuary, such as the envisaged dredging works in the Westerschelde. The weak synchronicity of developments in populations sampled at different stations seems to preclude a proper comparison between 'control' and 'impact' sites needed in a BACI design (before-after-control-impact; Underwood 1994, Ellis \& Schneider 1997, Hewitt et al. 2001, StewartOaten \& Bence 2001) for this type of impact. Controlimpact comparisons depend on the dominance of synchronous development over relatively large distances (for large impacts, this would be the region or total estuary scale of our study), and this was shown here to represent only a minor component of the variance for only a limited number of species. In contrast to this, before-and-after comparisons seem much more feasible, provided a number of conditions are met. We have shown that on a sufficiently long time scale (several years) assemblages and individual-species abundances correlate significantly with the environmental variables that are influenced by geomorphological changes ensuing from dredging operations (changes in bed level height, sediment composition, current velocities). It is possible that responses on shorter time scales would be visible, but insufficient within-year and within-station replication of sampling of environmental variables mean that we are unable to make firm statements about this possibility. Significant fractions of variance within and between stations remained unexplained by the measured environmental variables. This emphasises the need for further study of other factors influencing the assemblages, and anyway for sufficient replication of the sampling in order to preserve enough power to detect before-and-after changes. When properly replicated, hierarchical analyses of spatial and temporal variability can provide clues to the range and relative importance of processes (environmental factors, population and life-history processes and biotic interactions) that may be most important to organisms (Horne \& Schneider 1995, Zajac et al. 1998). Finally, we should emphasise the need to continually check the nature of the speciesenvironment relations in a changing estuary. To the degree that these relations are the indirect consequence of biotic interactions within the assemblage, there is no guarantee that they will remain unchanged when the physical forcing changes at a large scale. Inter-system comparisons of the species-environment relations could shed more light on this point.

Acknowledgements. The sampling programme was funded by Rijkswaterstaat (RWS). We thank A. Van der Pluym, B. Kornman, D. De Jong, B. Dauwe \& H. Verbeek from the National Institute for Coastal and Marine Management (RWS/RIKZ) for providing the data on the sedimentation-erosion measurements and chl a measurements and for fruitful discussions. We thank the CEME monitoring group (project leader H. Hummel) for the laboratory analysis and data management of the benthic macrofauna. T.Y. is supported by RIKZ under project RKS889. We are grateful to Dr Judi Hewitt for comments on an earlier draft. We also thank 3 anonymous referees for comments that improved the manuscript. This is contribution no. 3072 of the Netherlands Institute of Ecology.

\section{LITERATURE CITED}

Anderson MJ, Gribble NA (1998) Partitioning the variation among spatial, temporal and environmental components in a multivariate data set. Aust J Ecol 23:158-167

Andrew NL, Mapstone BD (1987) Sampling and the description of spatial pattern in marine ecology. Oceanogr Mar Biol Annu Rev 25:39-90

Archambault P, Bourget E (1996) Scales of coastal heterogeneity and benthic intertidal species richness, diversity and abundance. Mar Ecol Prog Ser 136:111-121

Baeyens W, van Eck B, Lambert C, Wollast R, Goeyens L 
(1998) General description of the Scheldt estuary. Hydrobiologia 366:1-14

Barry JP, Dayton PK (1991) Physical heterogeneity and the organization of marine communities. In: Kolasa J, Pickett STA (eds) Ecological heterogeneity. Springer-Verlag, New York, p 270-320

Benedetti-Cecchi L (2001) Variability in abundance of algae and invertebrates at different spatial scales on rocky sea shores. Mar Ecol Prog Ser 215:79-92

Beukema JJ, Essink K, Michaelis H (1996) The geographic scale of synchronized fluctuation patterns in zoobenthos populations as a key to underlying factors: climatic or man-induced. ICES J Mar Sci 53:964-971

Beukema JJ, Essink K, Dekker R (2000) Long-term observations on the dynamics of three species of polychaetes living on tidal flats of the Wadden Sea: the role of weather and predator-prey interactions. J Anim Ecol 69:31-44

Beukema JJ, Drent J, Honkoop PJC (2001) Maximizing lifetime egg production in a Wadden Sea population of the tellinid bivalve Macoma balthica: a trade-off between immediate and future reproductive outputs. Mar Ecol Prog Ser 209:119-129

Borcard D, Legendre P, Drapeau P (1992) Partialling out the spatial component of ecological variation. Ecology 73: 1045-1555

Cole RG, Healy TR, Wood ML, Foster M (2001) Statistical analysis of spatial pattern: a comparison of grid and hierarchical sampling approaches. Environ Monit Assess 69: 85-99

Constable AJ (1999) Ecology of benthic macro-invertebrates in soft-sediment environments: a review of progress towards quantitative models and predictions. Aust J Ecol 24: 452-476

Daemen EAMJ (1986) Comparison of methods for the determination of chlorophyll in estuarine sediments. Neth J Sea Res 20:21-28

De Jong DJ, De Jonge VN (1995) Dynamics and distribution of microphytobenthic chl $a$ in the Western Scheldt estuary (SW Netherlands). Hydrobiologia 311:21-30

Dekker L, Lievense P, van der Male C (1994) Calibratie en verificatie SCALDIS100. werkdocument RIKZ/AB-94.839x, Rijkswaterstaat, Rijksinstituut voor Kust en Zee

Ellis JI, Schneider DC (1997) Evaluation of a gradient sampling design for environmental impact assessment. Environ Monit Assess 48:157-172

Flach EC (1992) The influence of four macrozoobenthic species on the abundance of the amphipod Corophium volutator on tidal flats of the Wadden Sea. Neth J Sea Res 29: 379-394

Franquet E, Dolédec S, Chessel D (1995) Using multivariate analyses for separating spatial and temporal effects within species-environment relationships. Hydrobiologia 300/301: 425-431

Giménez L, Yannicelli B (2000) Longshore patterns of distribution of macroinfauna on a Uruguayan sandy beach: an analysis at different spatial scales and of their potential causes. Mar Ecol Prog Ser 199:111-125

Goosen NK, Kromkamp J, Peene J, van Rijswijk P, van Breugel P (1999) Bacterial and phytoplankton production in the maximum turbidity zone of three European estuaries: the Elbe, Westerschelde and Gironde. J Mar Syst 22:151-171

Graham MH, Edwards MS (2001) Statistical significance versus fit: estimating the importance of individual factors in ecological analysis of variance. Oikos 93:505-513

Heip CHR, Goosen NK, Herman PMJ, Kromkamp J, Middelburg JJ, Soetaert K (1995) Production and consumption of biological particles in temperate tidal estuaries. Oceanogr Mar Biol Annu Rev 33:1-150

Herman PMJ, Middelburg JJ, Van de Koppel J, Heip CHR (1999) Ecology of estuarine macrobenthos. Adv Ecol Res 29:195-240

Hewitt JE, Thrush SE, Cummings VD (2001) Assessing environmental impacts: effects of spatial and temporal variability at likely impact scales. Ecol Appl 11:1502-1516

Horne JK, Schneider DC (1995) Spatial variance in ecology. Oikos 74:18-26

Hughes TP, Baird AH, Dinsdale EA, Moltschaniwskyj, Pratchett MS, Tanner JE, Willis BL (1999) Patterns of recruitment and abundance of corals along the Great Barrier Reef. Nature 397:59-63

Hutchinson N, Williams GA (2001) Spatio-temporal variation in recruitment on a seasonal, tropical rocky shore: the importance of local versus non-local processes. Mar Ecol Prog Ser 215:57-68

Jones GP, Ferrell DJ, Sale PF (1990) Spatial pattern in the abundance and structure of mollusc populations in the soft sediments of a coral reef lagoon. Mar Ecol Prog Ser 62: $109-120$

Jongman RHG, ter Braak CFJ, Van Tongeren OFR (1995) Data analysis in community and lancscape ecology, 2nd edin. Cambridge University Press, Cambridge

Kendall MA, Widdicombe S (1999) Small scale patterns in the structure of macrofaunal assemblages of shallow soft sediments. J Exp Mar Biol Ecol 237:127-140

Lawrie SM, McQuaid CD (2001) Scales of mussel bed complexity: structure, associated biota and recruitment. J Exp Mar Biol Ecol 257:135-161

Legendre P, Thrush SF, Cummings VJ, Dayton PK, Grant J, Hewitt JE, Hines AH, McArdle BH, Pridmore D, Schneider DC, Turner SJ, Whitlach RB, Wilkinson MR (1997) Spatial structure of bivalves in a sandflat: scale and generating processes. J Exp Mar Biol Ecol 216:99-128

Levin SA (1992) The problem of pattern and scale in ecology. Ecology 73:1943-1967

Lindegarth M, André C, Jonsson PR (1995) Analysis of the spatial variability in abundance and age structure of two infaunal bivalves, Cerastoderma edule and C. lamarcki, using hierarchical sampling programs. Mar Ecol Prog Ser 116:85-97

Liu QH, Bråkenhielm S (1995) A statistical approach to decompose ecological variation. Water Air Soil Pollut 85: $1587-1592$

Morrisey DJ, Howitt L, Underwood AJ, Stark JS (1992a) Spatial variation in soft-sediment benthos. Mar Ecol Prog Ser 81:197-204

Morrisey DJ, Underwood AJ, Howitt L, Stark JS (1992b) Temporal variation in soft-sediment benthos. J Exp Mar Biol Ecol 164:233-245

Økland RH, Eilertsen O (1994) Canonical corresponce analysis with variation partitioning: some comment and an application. J Veg Sci 5:117-126

Ollabaria C, Chapman MG (2001) Comparison of patterns of spatial variation of microgastropods between two contrasting intertidal habitats. Mar Ecol Prog Ser 220:201-211

Schneider D (1994) Quantitative ecology: spatial and temporal scaling. Academic Press, New York

Searle SR, Casella G, McCulloch CE (1992) Variance components. Wiley Interscience, New York

Soetaert K, Herman PMJ (1995) Estimating estuarine residence times in the Westerschelde (The Netherlands) using a box model with fixed dispersion coefficients. Hydrobiologia 311:215-224

Stewart-Oaten A, Bence JR (2001) Temporal and spatial vari- 
ation in environmental impact assessment. Ecol Monogr 71:305-339

Ter Braak CJF (1986) Canonical Correspondence Analysis: a new eigenvector technique for multivariate direct gradient analysis. Ecology 67:1167-1179

ter Braak CJF, Smilauer P (1998) CANOCO Reference Manual and user's guide to Canoco for windows: software for Canonical Community Ordination (version 4). Microcomputer Power, Ithaca, NY

ter Braak CJF, Verdonschot PFM (1995) Canonical correspondence analysis and related multivariate methods in aquatic ecology. Aquat Sci 57:255-289

Thrush SF, Hewitt JE, Pridmore RD (1989) Patterns in the spatial arrangement of polychaetes and bivalves in intertidal sandflats. Mar Biol 102:529-536

Thrush SF, Schneider DC, Legendre P, Whitlatch RB and 9 others (1997a) Scaling-up from experiments to complex ecological systems: Where to next? J Exp Mar Biol Ecol 216:243-254

Thrush SF, Cummings VJ, Dayton PK, Ford R and 11 others (1997b) Matching the outcome of small-scale density manipulation experiments with larger scale patterns: an example of bivalve adult/juvenile interactions. J Exp Mar Biol Ecol 216:153-169

Thrush SF, Lawrie SM, Hewitt JE, Cummings VJ (1999) The problem of scale: uncertainties and implications for softbottom marine communities and the assessment of human impacts. In: Gray JS, Ambrose WG, Szaniawska A (eds) Biogeochemical cycling and sediment ecology. Kluwer Academic Publishers, Dordrecht, p 195-210

Turner SJ, Grant J, Pridmore RD, Hewitt JE, Wilkinson MR, Hume T, Morrisey D (1997) Bedload and water-column transport and colonisation processes by post-settlement

Editorial responsibility: Otto Kinne (Editor),

Oldendorf/Luhe, Germany benthic macrofauna: does infaunal density matter? J Exp Mar Biol Ecol 216:51-75

Underwood AJ (1994) On beyond BACI: sampling designs that might reliably detect environmental disturbances. Ecol Appl 4:3-15

Underwood AJ (1997) Experiments in ecology: their logical design and interpretation using analysis of variance. Cambridge University Press, Cambridge

Underwood AJ, Chapman MG, Connell SD (2000) Observations in ecology: you can't make progress on processes without understanding the patterns. J Exp Mar Biol Ecol 250:97-115

Volckaert F (1987) Spatial pattern of soft bottom polychaeta of Nova Scotia, Canada. Mar Biol 93:627-639

Wiens JA (1989) Spatial scaling in ecology. Funct Ecol 3: 385-397

Ysebaert T (2000) Macrobenthos and waterbirds in the estuarine environment: spatio-temporal patterns at different scales. Communications of the Institute of Nature Conservation 16, Brussels

Ysebaert T, Meire P, Coosen J, Essink K (1998) Zonation of intertidal macrobenthos on estuaries of Schelde and Ems. Aquat Ecol 32:53-71

Ysebaert T, Meire P, Herman PMJ, Verbeek H (2002) Macrobenthic species response surfaces along estuarine gradients: prediction by logistic regression. Mar Ecol Prog Ser 225:79-95

Zajac RN, Whitlatch RB, Thrush SF (1998) Recolonization and succession in soft-sediment infaunal communities: the spatial scale of controlling factors. Hydrobiologia 375/376: 227-240

Zar JH (1996) Biostastical analysis, 3rd edn. Prentice-Hall International, Englewood Cliffs, NJ

Submitted: December 9, 2001; Accepted: June 19, 2002 Proofs received from author(s): November 13, 2002 